\title{
An LCA-based model for assessing prevention versus non-prevention of construction waste in buildings
}

\author{
C. Llatas $^{\mathrm{a}, *}$, N. Bizcocho ${ }^{\mathrm{b}}$, B. Soust-Verdaguer ${ }^{\mathrm{a}}$, M.V. Montes ${ }^{\mathrm{a}}$, R. Quiñones ${ }^{\mathrm{a}}$ \\ ${ }^{a}$ Instituto Universitario de Arquitectura y Ciencias de la Construcción, Escuela Técnica Superior de Arquitectura, Universidad de Sevilla, Av. de la Reina Mercedes 2, 41012 Sevilla, Spain \\ ${ }^{\mathrm{b}}$ Departamento de Mecánica de Medios Continuos y Teoría de Estructuras. Escuela Politécnica Superior, Universidad Carlos III de Madrid, Avda. de la Universidad 30, 28911 Leganés, Spain
}

\section{ARTICLE INFO}

\section{Article history:}

Received 30 November 2020

Received in revised form 14 March 2021

Accepted 26 March 2021

Available online $\mathrm{xxx}$

\section{Keywords}

Life Cycle Assessment (LCA)

Construction Waste (CW)

Prevention

Design

Building

Waste management

\begin{abstract}
A B S T R A C T
Waste generated by the Construction Sector represents an environmental problem in many countries. To achieve increasingly eco-efficient waste management, Life Cycle Assessment (LCA) provides an objective method for the quantification of the potential impact that waste management exerts on the environment. Traditionally, LCA has focused on the evaluation of non-prevention scenarios once the waste is generated, mainly by showing the benefits of recycling vs. disposal. Consequently, the literature has hardly addressed the positive environmental impacts caused by waste prevention, that is, the reduction at source, which constitutes the preferred option of any waste management hierarchy. Therefore, this study proposes a model to simulate the environmental performance of the prevention vs. the non-prevention of construction waste production. The model is applied to an urban system of residential buildings in Spain. The results provide evidence of the environmental benefits achieved with the prevention scenario. The prevention scenario reduces the construction waste generated in the non-prevention scenarios by up to $57 \%$. Furthermore, it allows a potential reduction of up to 4.6 and 171.1 times the impact caused by the disposal scenario; and up to 1.7 and 8.3 times those of the recycling scenario. The model can be implemented in other contexts with other reference buildings, and enables the environmental benefits of reduction strategies to be studied, thereby providing a tool to guide and support decision-making during the building design stage. Moreover, the results obtained can help professionals and policymakers to incorporate effective construction waste prevention measures in waste prevention plans and programs.
\end{abstract}

(C) 2021

\section{Introduction}

Construction and Demolition Waste (CDW) generation represents an environmental problem in many countries. In the EU, CDW comprises the largest waste stream, 36\% of all waste generated (Eurostat, 2018). The construction sector requires vast amounts of resources and accounts for about $50 \%$ of all extracted material (European Commission, 2020a). The inefficient use of resources has an impact on the environment. Greenhouse gas (GHG) emissions from material extraction, manufacturing of construction products, construction, and renovation

Abbreviations: ADP, Abiotic Depletion Potential; AP, Acidification Potential; BIM, Building Information Modeling; CDW, Construction and Demolition Waste; CTE, Código Técnico de la Edificación; CW, Construction Waste; ED, Energy Demand; EN, European Standard; EP, Eutrophication Potential; EU, European Union; GHG, Greenhouse gas; GWP, Global Warming Potential; HTP, Human Toxicity Potential; ISO, International Organisation for Standardization; LCA, Life Cycle Assessment; LCI, Life Cycle Inventory; LCIA, Life Cycle Impact Assessment; MH, (mirror) Hazardous; MNH, (mirror) Non Hazardous; MSW, Municipal Solid Waste; NPS, Non-Prevention scenario; O1, Option 1; O2, Option 2; ODP, Ozone Depletion Potential; POP, Photochemical Ozone Potential; PS, Prevention scenario; $\mathrm{RB}$, Reference Building.

* Corresponding author.

E-mail address: cllatas@us.es (C. Llatas) of buildings are estimated at $5-12 \%$ of total national GHG emissions (European Commission, 2020a). To reduce environmental and climate impacts, prevention is the preferred option for any waste hierarchy (European Commission-JRC, 2018). In fact, in the EU the reduction of the amount of waste generated takes precedence over the maximisation of recycling and re-use in procurement processes (European Commission-JRC, 2016). Furthermore, several initiatives, such as the European Green Deal (European Commission, 2019), the EU framework Level(s) (European Commission-JRC, 2021), and the forthcoming strategy for a sustainable built environment (European Commission, 2021), are committed to a more resource-efficient construction and waste prevention. However, the new Circular Economy Action Plan recognises that, despite efforts at both EU and national levels, the amount of waste generated is not diminishing (European Commission, 2020b).

The scientific community has emphasised the key role of the building design stage in preventing CDW (e.g., Bossink and Brouwers, 1996; Poon and Jaillon, 2002; Osmani et al., 2008; Won et al., 2016; Llatas and Osmani, 2016.), although research efforts towards the reduction of CDW production still appear limited when compared with recycling studies (Yuan and Shen, 2011). Many approaches address the causes and strategies for the reduction of CDW, but there re- 
mains a lack of studies that investigate the environmental consequences of preventing CDW production. Moreover, research endeavours over recent decades (Craighill and Powell, 1999; Blengini, 2009; Ortiz et al., 2010; Martínez et al., 2013) have been largely focused on showing the environmental benefits of recycling CDW rather than on its actual reduction. Consequently, there is a wide gap in the literature regarding the environmental impact related to CDW prevention, which is mainly due to the lack of quantitative environmental assessment methods that include prevention.

Therefore, this study presents a model based on Life Cycle Assessment (LCA) standards (ISO, 2006a; 2006b). The main innovation therein is that it enables the evaluation of prevention scenarios (PS) vs. non-prevention scenarios (NPS) of the construction stage of new buildings, defined as follows:

- PS that apply prevention measures to baseline scenarios (e.g., they design waste-reduction strategies that reduce construction waste (CW) generation at source).

- NPS are baseline scenarios that do not apply prevention measures and treat the CW once generated (e.g., they re-use, recycle, and/or incinerate).

A real-world case study was carried out on Spanish residential buildings to verify the implementation of the LCA model. The model simulates various scenarios and quantifies the environmental impacts caused by PS vs. those caused by NPS, and hence provides a tool to guide and support decision-making during the design stage, thereby contributing towards the challenge of achieving increasingly efficient buildings.

\section{LCA and prevention scenarios (PS) versus non-prevention scenarios (NPS)}

\subsection{LCA and NPS}

LCA has become one of the most objective and useful quantitative methods for the evaluation of the environmental impact of buildings (Bahramian and Yetilmezsoy, 2020). In the field of CDW, its main development has been the so-called "traditional LCA" (Nessi et al., 2013; Bizcocho and Llatas, 2019), which employs various approaches to assess potential environmental impacts caused by CDW management options, once CDW is generated:

- To express the environmental benefits achieved with the recycling of separated waste fractions (Grant and James, 2005; DECCW, 2010) and with that of mixed waste (Blengini and Garbarino, 2010; Mercante et al., 2012).

- To show the benefits achieved with the use of recycled materials vs. the use of natural materials (Marinković et al., 2010; Pantini et al, 2018; Yazdanbakhsh, 2018).

- To compare the impacts of various NPS, by showing the benefits of re-use and recycling with respect to disposal: (i) recycling vs. disposal (Craighill and Powell, 1999; Blengini, 2009; Butera et al., 2015; Penteado and Rosado, 2016; Vitale et al., 2017); (ii) re-use vs. recycling vs. disposal (Balazs et al., 2001; Martínez et al., 2013; Xia et al., 2020); (iii) recycling vs. incineration (Rivela et al., 2006); (iv) recycling vs. disposal vs. incineration (Jambeck et al., 2007; Ortiz et al., 2010); (v) recycling vs. downcycling vs. disposal (Di Maria et al., 2018).

These studies contribute to the Circular Economy challenges that aim to extend the life cycle of waste materials by reducing the flow of waste once it has been generated (mainly in the end-of-life phase); the prevention of waste production at source, however, is not addressed. Furthermore, a major handicap to comparing results between different evaluations is the lack of standardisation both in the functional unit and in the system boundary (Bovea and Powell, 2016).

\subsection{LCA and PS}

Within the European framework, "waste prevention" is any measure taken before a substance, material or product becomes waste, that reduces: (a) the quantity of waste, including reduction through re-use of products or extension of product lifespan; (b) adverse impacts of generated waste on the environment and human health; and (c) the content of hazardous substances in materials and products (European Commission, 2018a). Waste prevention is the most efficient way to improve resource efficiency and to reduce the environmental impact of waste. EU Member States are requested to prepare national waste prevention programs, in which waste managers and policymakers have to address prevention. Several studies highlighted the limitations of "traditional LCA" regarding the ability of waste management to include waste prevention (Ekvall et al., 2007; Nessi et al., 2013). It is employed to compare NPS, in which the functional unit is usually the amount of waste generated, equal in all NPS, and the system boundaries include the processes once the waste is generated, that is, downstream processes (e.g., sorting, transport to waste treatment facility, and waste processing). Moreover, Gheewala (2009) revealed the inability of "traditional LCA" to include the effects of waste prevention activities in the responsibilities of waste management, and the limitations in the applicability of the methodology as a decision support tool in waste management planning and policymaking: these are to be addressed in future research.

\subsubsection{LCA and municipal solid waste (MSW) prevention}

In order to overcome the aforementioned limitation, various studies address the inclusion of prevention in LCA waste management, mainly in the field of MSW. Cleary (2010) proposed an approach named WasteMAP LCA (Waste Management and Prevention LCA), and subsequently evaluated the life cycle effects of waste prevention activities on a residential waste management system (Cleary, 2014). Nessi et al. (2013) identified the two main methodological milestones:

- The redefinition of the functional unit. With prevention, the same functional unit cannot be used in all scenarios, since certain scenarios appear with less waste.

- The redefinition of the system boundaries. With prevention, the processes before the waste is generated (i.e., upstream processes) must be considered.

Other LCA studies applied to MSW detect priority waste streams for prevention (e.g., food in Sakai et al., 2017). Further developments implement tools, such as WARM (EPA, 2019), where generic energy factors are employed to estimate GHG emission reductions and energy savings.

\subsection{2. $L C A$ and $C D W$ prevention}

In the field of CDW, the inclusion of waste prevention in LCA is addressed in Bizcocho and Llatas (2019), where two models are developed: one general and one simplified. However, the incidence of building materials added $(+\mathrm{m})$ or avoided $(-\mathrm{M})$ in the PS is not considered (see Fig. 1 and Section 3.3). The study was also limited to a single waste fraction (concrete), of a single building, thus requiring further development. Moreover, this study reveal that the main barrier to the application of LCA to buildings when prevention activities are included is the considerable investment of time, which is largely due to the complexity in performing the inventory phase in a building. The incorporation of upstream processes from prevention activities, aggravates this issue, which provides evidence that simplification is required. Therefore, given the lack of attention that the scientific community has paid to the study of the environmental effects of CDW prevention, the interest in developing tools that support waste prevention programs, and the opportunity provided by the previous models developed in the field 


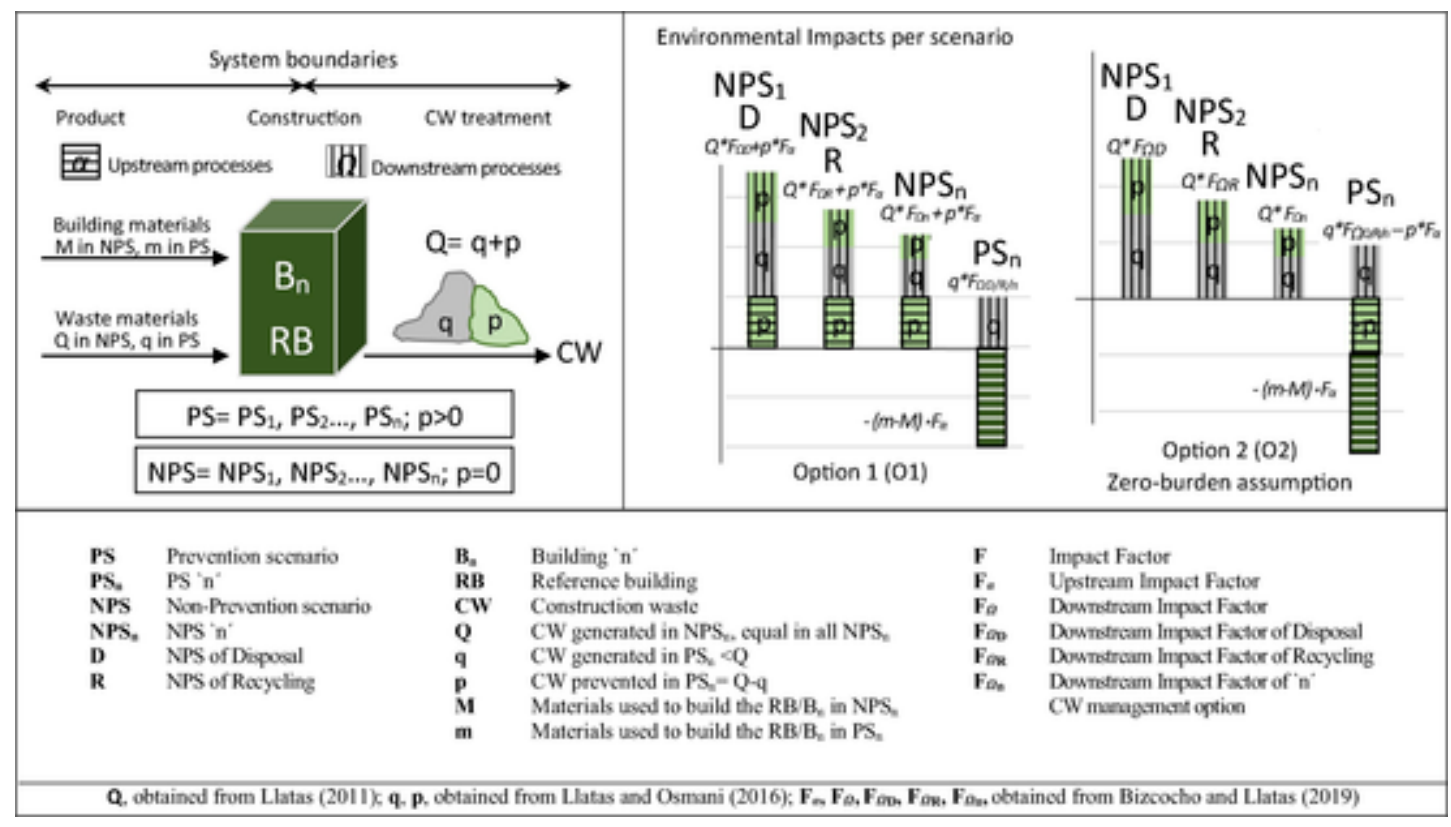

Fig. 1. Variables of the model.

of CDW prevention (Llatas, 2011; Llatas and Osmani, 2016; Bizcocho and Llatas, 2019), this study presents a model for the quantification of the environmental impact of various CW management scenarios, including CW prevention.

\section{Method}

This study aims to simulate the management of waste generated during the construction stage of new buildings (CW) in PS vs. NPS, as shown in Fig. 1. The use and end-of-life stages of the building fall outside the scope of this study. $\mathrm{PS}_{\mathrm{n}}$, is the $\mathrm{n}^{\text {th }}$ PS, which reduces the amount of CW at source through design waste reduction strategies, while $\mathrm{NPS}_{\mathrm{n}}$, is the $\mathrm{n}^{\text {th }}$ NPS, which considers waste management options, such as recycling and disposal, once CW has been generated. This evaluation can be conducted in the design phase and can serve as a decision-making tool for the selection of building elements with a low environmental impact. An integrated urban system of buildings is used as a basis to obtain the variables of the Model. Within this system, a representative building, called the Reference Building (RB), is configured to obtain the generic environmental impact factors. Subsequently, the quantification can be performed of the environmental impact of any building at this location with similar characteristics. Fig. 1 shows the main variables of the Model and the two methodological options (see Section 3.5.2.), which can be obtained through the 5 steps described below. Finally, a case study shows the usefulness of the Model.

\subsection{Step 1. Selection of an integrated urban system of buildings}

An Integrated Urban System of Buildings, defined as "a group of interrelated buildings number " $\mathrm{n}$ " $\left(\mathrm{B}_{\mathrm{n}}\right)$ with similar typological and constructive characteristics in a geographical area", is selected. Within this system, two subsystems are identified: a Material Manufacturing Subsystem, which includes manufacturers and suppliers of building materials; and a Waste Management Subsystem, which includes the necessary facilities for CW treatment.

\subsection{Step 2. Quantification of CW in NPS}

This step quantifies "Q", the CW generated in NPS (see Fig. 1). To analyse "Q", equal in all NPS $\mathrm{N}_{\mathrm{n}}$, it is necessary to identify and quantify the $\mathrm{CW}$ generated for each building $\left(\mathrm{B}_{\mathrm{n}}\right)$. A CW quantification model
(Llatas, 2011), based on quantification factors, links the construction procedures adopted in the project with the types and quantities of CW generated, thereby obtaining "Q" listed in accordance with the European List of Waste (LoW) (European Commission, 2014).

\subsection{Step 3. Application of CW prevention strategies and quantification of $C W$ in $P S$}

This step quantifies "q", "p", "m", and "M" (see Fig. 1). Subsequently, the CW prevention strategies are developed in $\mathrm{PS}_{\mathrm{n}}$ by using a CW reduction model (Llatas and Osmani, 2016), which links the design variables that affect $\mathrm{CW}$ reduction with the types and quantities of CW reduced. This model applies both soft (e.g., modulation, standardisation, and optimisation) and hard design reduction strategies (e.g., re-use of CDW and cleaner technologies) to the original building elements in the NPS ${ }_{\mathrm{n}}$. Alternative low-waste building elements in $\mathrm{PS}_{\mathrm{n}}$ are obtained and the amount of CW generated in $\mathrm{PS}_{\mathrm{n}}$ (q) is quantified and listed according to the European LoW (European Commission, 2014). The amount of CW prevented (p) is obtained by subtracting "q" from "Q".

Two types of alternative low-waste building elements can be used in $\mathrm{PS}_{\mathrm{n}}$ :

(i) Reductive building elements, which reduce CW and do not modify the materials of the original building elements. For example, the use of modular coordinated brick walls instead of uncoordinated brick walls reduces CW, prevent brick breakages, and the materials included within both brick walls (bricks, mortar) are equal.

(ii) Substitute building elements, which reduce CW but modify the materials of the original building elements. For example, the use of precast concrete, instead of concrete cast in situ, reduces CW, prevents concrete losses, and obviates the need for timber formworks, but the materials have been modified since they have been manufactured differently.

This differentiation was considered in previous studies (Nessi et al., 2013; Bizcocho and Llatas, 2019), since those processes added and avoided due to the use of alternative building elements should be considered. Therefore, " $\mathrm{m}-\mathrm{M}$ " is obtained only for substitute building elements, since, in the reductive building elements, $\mathrm{m}=\mathrm{M}$, and consequently $\mathrm{m}-\mathrm{M}=0$, where " $\mathrm{m}$ " is the amount of the materials for the al- 
ternative building element in $\mathrm{PS}_{\mathrm{n}}$, and "M" represents those for the original building element in $\mathrm{NPS}_{\mathrm{n}}$.

\subsection{Step 4. Reference building ( $R B$ ) configuration}

An $\mathrm{RB}$ is proposed, since the location of the buildings plays a crucial role in the LCA results, mainly due to waste transportation and the distances between the working site and the waste management facilities (Blengini and Garbarino, 2010; Mercante et al., 2012; Bizcocho and Llatas, 2019; Pantini and Rigamonti, 2020). The RB is defined as "a theoretical building, located in the geometric centre of an Integrated Urban System of Buildings, whose types and amounts of CW generated and prevented are representative of these building systems". According to this definition, the CW of the RB generated in the $\mathrm{PS}_{n}$ and $\mathrm{NPS}_{n}$ is obtained from the average of the interrelated buildings $\left(B_{n}\right)$ that comprise this system. The RB marks the geographical point of supply of building materials and CW generation with respect to which the distances, a key parameter, of the Material Manufacturing Subsystem (e.g., material manufacturers, suppliers) and the Waste Management Subsystem (e.g., recycling plants, landfills), will be considered in order to calculate the generic environmental impact factors.

\subsection{Step 5. Quantifying environmental impacts in PS vs. NPS}

The method for quantifying the environmental impact follows the methodological framework described in the LCA standards (ISO, 2006a; 2006b). A simplified calculation procedure is developed from Bizcocho and Llatas (2019), starting from the assumption that the total impacts of all the CW generated in a scenario are considered equal to the sum of the partial impact of each CW fraction generated. This assumption is also considered for the quantification of global impacts accumulated from partial impacts of processes in LCA on buildings (EN, 2011). The partial impact associated with each CW fraction is obtained by multiplying the value of the impact per ton $(F)$, known as the impact factor, by the total of tons generated ( $\mathrm{q}$ in $\mathrm{PS}_{\mathrm{n}}$, Q in $\mathrm{NPS}_{\mathrm{n}}$,). "F" is obtained in accordance with the simplified model proposed in Bizcocho and Llatas (2019).

\subsubsection{Quantifying generic impact factors (F)}

To obtain "F", both the CW upstream processes $(\alpha)$ regarding the Material Manufacturing Subsystem and the CW downstream processes $(\Omega)$ regarding the Waste Management Subsystem are considered for each type of CW managed. Upstream Impact Factors $(\mathrm{F} \alpha)$ include the environmental impact due to the necessary processes from the extraction of 1 ton of CW until it becomes waste (raw material, transport to manufacturer, manufacture, transport to the building site, and construction processes). "F $\alpha$ " are also considered in those building materials added $(+\mathrm{m})$ or avoided $(-\mathrm{M})$ through the substitute building elements. Downstream Impact Factors $\left(\mathrm{F}_{\Omega}\right)$ include the environmental impact caused by the treatment of 1 ton of $\mathrm{CW}$ once generated (sorting, transport to waste treatment facility, processing in recycling or disposal facility). CW re-use is excluded from the analysis. "F" can be calculated specifically for each building $\left(\mathrm{B}_{\mathrm{n}}\right)$. However, the simplified procedure proposes using generic "F" quantified for a representative building, in this case, the RB.

\subsubsection{Quantifying environmental impacts}

Finally, having obtained the variables of the model $(\mathrm{Q}, \mathrm{q}, \mathrm{p}, \mathrm{m}, \mathrm{M}$, $F_{\alpha}, F_{\Omega}$ ) (see Fig. 1), the environmental impact can be quantified. The calculation procedure considers both the additional processes, as well as the avoided processes introduced as a result of the application of $\mathrm{CW}$ prevention strategies, during the construction stage. The alternative building elements modify both building materials (bricks, concrete, iron, etc., used in the building), and waste materials (building materials and their packaging supplied but left unused in the building, due to losses, breakages, etc.). Therefore, the additional and avoided upstream of building materials (m-M) are included together with the additional and avoided upstream and downstream of waste materials (q-Q). In addition, the analytical expressions are reformulated to consider the variables " $\mathrm{m}$ " and "M", which were not previously considered in Bizcocho and Llatas (2019).

Fig. 1 shows two methodological options, whose main difference lies in the system boundaries. Both options consider downstream impacts in all scenarios, since they include CW management. In NPS, the impact is greater than in PS since the amount of CW generated is greater $(\mathrm{Q}>\mathrm{q})$. The difference between the two options lies in the way of allocating the upstream processes of the prevented CW $(\mathrm{p}=\mathrm{Q}-\mathrm{q})$. In Option 1 (O1), upstream processes are included in the form of added loads in NPS, while Option 2 (O2) applies the "zero-burden assumption" (Ekvall et al., 2007) as the "traditional LCA". Therefore, in O2, the NPS do not include upstream processes of CW because these are equal in all NPS, and the avoided loads of the upstream processes of the prevented CW are allocated in the PS. Note that the net impact between the scenarios is the same in both options. Likewise, both options consider in the PS the upstream processes of the added and avoided materials (m-M). O1 estimates the impact using Eq. (1) and Eq. (2), while O2 uses Eq. (3) and Eq. (4).

$$
\begin{aligned}
X_{N P 1}^{j} & =\sum_{i}^{n} Q_{i} \times F \Omega_{i}^{j}+\sum_{i}^{n}\left(q_{i}-Q_{i}\right) \times F \alpha_{i}^{j} \\
X_{P 1}^{j} & =\sum_{i}^{n} q_{i} \times F \Omega_{i}^{j}-\sum_{i}^{n}\left(m_{i}-M_{i}\right) \times F \alpha_{i}^{j} \\
X_{N P 2}^{j} & =\sum_{i}^{n} Q_{i} \times F \Omega_{i}^{j} \\
X_{P 2}^{j} & =\sum_{i}^{n} q_{i} \times F \Omega_{i}^{j}-\sum_{i}^{n}\left(q_{i}-Q_{i}\right) \times F \alpha_{i}^{j} \\
& -\sum_{i}^{n}\left(m_{i}-M_{i}\right) \times F \alpha_{i}^{j}
\end{aligned}
$$

where $X_{N P 1}^{j}$ is impact " $\mathrm{j}$ ” of an NPS $\mathrm{n}$ in $\mathrm{O} 1 ; X_{P 1}^{j}$ is impact " $\mathrm{j}$ ” of a $\mathrm{PS}_{\mathrm{n}}$ in $\mathrm{O} 1 ; X_{N P 2}^{j}$ is impact " $\mathrm{j}$ " of an $\mathrm{NPS}_{\mathrm{n}}$ in $\mathrm{O} 2 ; X_{P 2}^{j}$ is impact " $\mathrm{j}$ " of a $\mathrm{PS}_{\mathrm{n}}$ in O2; $Q_{i}$ is the quantity in tons of the fraction $i$ of CW generated on-site without applying prevention measures in an NPS ${ }_{\mathrm{n}} ; q_{i}$ is the quantity in tons of the fraction $i$ of $\mathrm{CW}$ generated on-site by applying prevention measures in a $\mathrm{PS}_{\mathrm{n}} ; M_{i}$ is the quantity in tons of the building material $i$ necessary to construct the building elements in an NPS $; m_{i}$ is the quantity in tons of the building material $i$ necessary to construct the building in a $\mathrm{PS}_{\mathrm{n}} ; F \alpha_{i}^{j}$ is impact " $\mathrm{j}$ " associated with the upstream processes of 1 ton of the fraction $i$ of generated $\mathrm{CW}$ or those of 1 ton of building material $i$ necessary to construct the building elements; and $F \Omega_{i}^{j}$ is impact " $\mathrm{j}$ " associated with the downstream processes of 1 ton of the fraction $i$ of generated CW.

\subsubsection{LCA-based calculation phases}

Based on all the aforementioned aspects, additional issues are considered in the LCA phases according to current standards (ISO, 2006a; 2006b).

3.5.3.1. Definition of goal and scope The Integrated Urban System of Buildings in a specific location is selected, together with the CW fractions and the CW management scenarios to be analysed. The functional unit is defined as "the management of the CW of a building which fulfils a given set of functions in a location" (Bizcocho and Llatas, 2019). The system boundaries are established depending on each methodological option. Regarding the procedures of load allocation, the "avoided load" or "system expansion" approach (Finnveden et al., 2009) can be applied in order to solve the problem of allocation in recycling cases. In addition, the assumptions adopted may be indicated. 
3.5.3.2. Life cycle inventory (LCI) For each fraction of CW prevented (q-Q), and for each building material added or avoided (m-M), the data of the processes involved in each scenario are collected. The data sources, in order of priority, include primary data collected directly from the companies involved (e.g., raw material, energy (electricity, NG, etc.), and wastes (emissions as well as solid waste), followed by secondary data obtained from official data, public databases, and bibliography. The group of interrelated facilities and processes at a location that involve upstream processes forms part of the Material Manufacturing Subsystem and the group of those that involve downstream processes forms part of the Waste Management Subsystem.

3.5.3.3. Life cycle impact assessment (LCIA) Environmental impact is evaluated using the CML 2001 method (Guinée et al., 2001) according to the categories of Climate Change (GWP), Acidification (AP), Eutrophication (EP), Stratospheric Ozone Depletion (ODP), Human Toxicity (HTP), and Photochemical Oxidation (POP). Primary Energy (ED) is also calculated by the Cumulative Energy Demand method. To quantify the impact, LCA software, such as SimaPro or GaBi, can be used.

3.5.3.4. Analysis of results The model enables the impact to be ascertained according to the two methodological options, in terms of CW fractions, in terms of CW management scenario, for the entire building, etc. One utility of the model can be the use of quantitative indicators that make it possible to compare not only $\mathrm{CW}$ management scenarios, but also the impact that buildings have due to their CW management. These indicators can form a basis for the creation of benchmarks for CW management in buildings at a location.

\subsection{Case study}

A case study is developed to verify the model. A group of 8 actual residential buildings $\left(\mathrm{B}_{1}-\mathrm{B}_{8}\right)$ promoted by a public developer (EMVISESA, 2020) was selected (Table 1). These buildings were analysed in the framework of two research projects (Spanish Government, 2018; Andalusian Government, 2020).

\section{Results and major findings}

\subsection{Integrated Urban system of buildings}

The Integrated Urban System of Residential Buildings $\left(\mathrm{B}_{1}-\mathrm{B}_{8}\right)$ in Seville, Spain, and both the Material Manufacturing Subsystem, and the Waste Management Subsystem were analysed (Bizcocho, 2014; Bizcocho and Llatas, 2019). Fig. 2 shows the location of the buildings and the main waste treatment facilities. Table 1 shows the similar typological and constructive characteristics of the buildings. All of these constructions were multi-family housing with 5 to 9 storeys with structural systems mainly made of cast-in-situ concrete, and with façades and partitions of brick walls. These building systems were used in the baseline NPS. All buildings, as well as their alternative systems in the PS, were designed in compliance with the minimum functional and technical requirements in Spain (CTE, 2006).

Table 1

Characteristics of an urban system of residential buildings in seville.

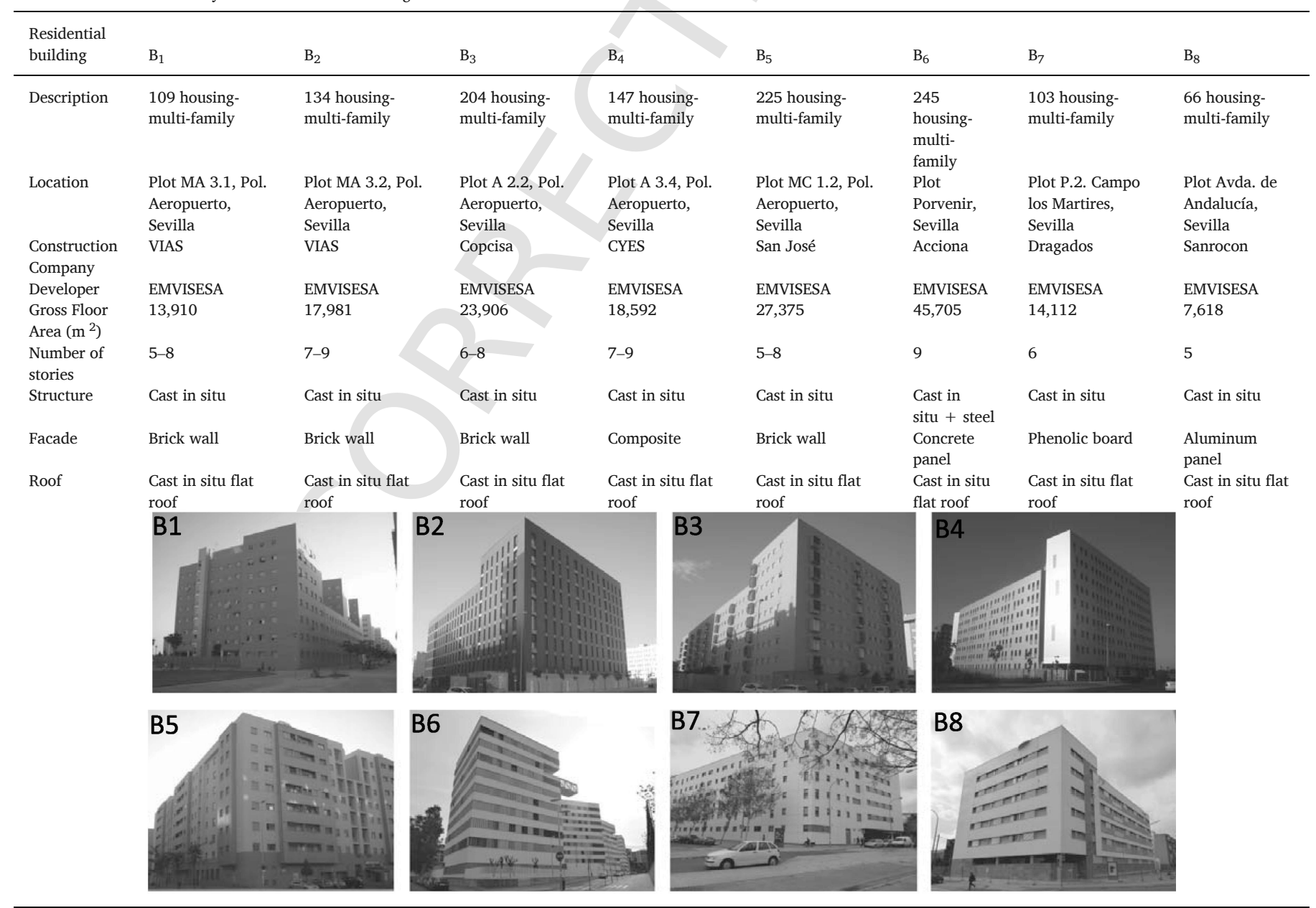




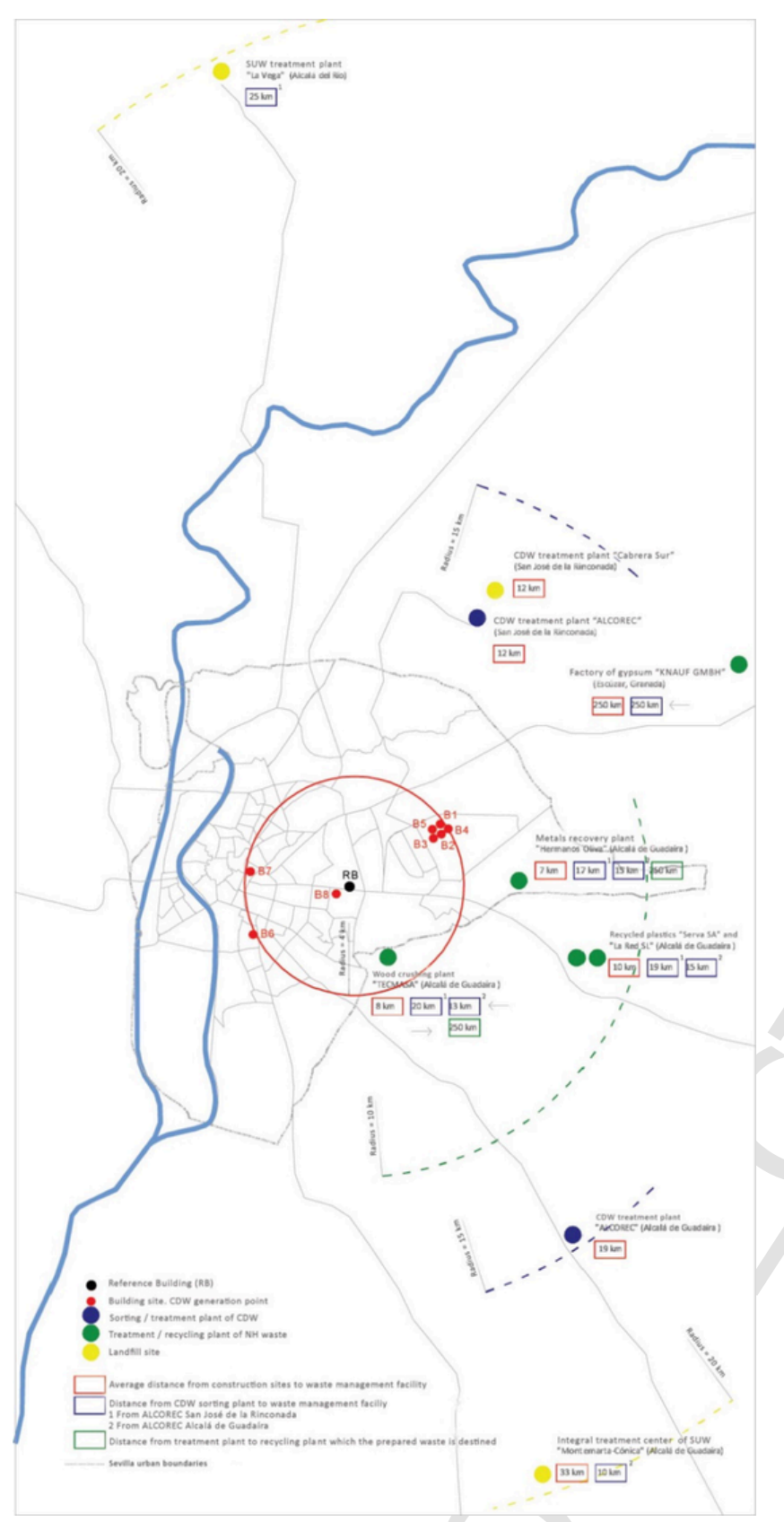

Fig. 2. Location of buildings $\left(B_{1}-B_{8}\right)$, Reference Building $(R B)$ and CW management facilities in Seville.

\section{2. $C W$ generated in NPS}

The CW was quantified in NPS and listed according to the European LoW (European Commission, 2014). In order to automate the calculations, a tool developed under a research project (Andalusian Government, 2020) was employed. The main CW fractions were identified, and the amount $(\mathrm{Q})$ was estimated, whereby ratios of $\mathrm{CW}$ generation between $0.073 \mathrm{t} / \mathrm{m}^{2}\left(\mathrm{~B}_{7}\right)$ and $0.127 \mathrm{t} / \mathrm{m}^{2}\left(\mathrm{~B}_{2}\right)$ were obtained (see Supplementary Table 1$)$.

Other studies in Spain handle similar CW generation ratios: for example, $0.107 \mathrm{t} / \mathrm{m}^{2}$ in Andalusia (CGATE and CSCAE, 2020). The highest ratio was in $B_{2}$, due to the greater number of elements produced on site. Most of the CW was inert and of a stony nature, with concrete and ceramic fractions, due to the building systems used. An- other source of CW was wood from the timber formworks and the wooden pallets upon which the bricks, vaults, etc. were supplied. This composition of CW is consistent with data in Spain, in which minerals and wood are the two main streams of CDW (Spanish National Institute of Statistics, 2017).

\subsection{CW prevention strategies and CW generated in PS}

The CW prevention strategies were applied in the PS. The building elements in the NPS are the original elements, and the building elements in the PS are assumed as alternatives, which can be either substitute or reductive building elements. Table 2 shows the main original building elements in NPS, the main alternative substitute and reductive building elements in PS and the reduction achieved. The building materials avoided $(-\mathrm{M})$ and added $(+\mathrm{m})$ with the alternatives were obtained mainly from BCCA (Andalusian Government, 2017) and are also included in Table 2. The functional unit is related to the unit of measure of each building element in this database. Zero (0) values are considered ("m-M" column) in those cases that are reductive building elements. The last row shows the values obtained for the entire alternative $\mathrm{RB}$, while considering the total quantity of each building element.

The amount of CW generated (q) in PS was obtained. Overall CW reductions between $42.5 \%\left(\mathrm{~B}_{7}\right)$ and $60.7 \%\left(\mathrm{~B}_{6}\right)$ were achieved (see Supplementary Table 2). Other studies obtained different percentages: $52 \%$ (Jaillon et al., 2008), 84.7\% (Tam et al., 2007a), and 100\% (Tam et al. 2007b), which depended on the level of prefabrication of the building.

\subsection{Reference building $(R B)$}

An RB is configured from three parameters: (i) typological characteristics, surface, and location; (ii) CW generated in NPS (Q); and (iii) CW generated (q) and prevented (p) in PS. (i) The buildings under study were located in Seville within a radius of $4 \mathrm{~km}$, with the RB as a "virtual $21,150 \mathrm{~m}^{2}$ residential building" located in the centre of this circle (Fig. 2) and potentially materialised with these building systems (Table 1). (ii) The composition of the CW generated in NPS (Q) in RB, was obtained from the average of the buildings (see Supplementary Table 1). A CW generation ratio of $0.117 \mathrm{t} / \mathrm{m}^{2}$ was attained. (iii) The composition of CW generated in PS (q) in RB, was obtained from the average of the buildings (see Supplementary Table 2). An average CW reduction of $57 \%$ was attained. The amount of CW prevented (p) was obtained by subtracting "q" from "Q". Table 3 includes the values of "Q", "q" and "p" in RB.

\subsection{Environmental impact in PS vs. NPS}

\subsubsection{Goal and scope}

The goal and scope of this LCA was to compare the environmental impact due to PS vs. NPS in the RB of an Integrated Urban System of Residential Buildings (Table 1) in Seville, Spain. The functional unit was the management of the CW generated during the construction of a $21,150 \mathrm{~m}^{2}$ residential building in Seville, which is equal to 2,472 tons of CW in NPS, following the composition of "Q" (Table 3) and 1,060 tons of CW in PS, following the composition of "q" (Table 3). The methodological option used was that of O2 (Fig. 1), since it is closest to "traditional LCA", which is a long-established method to assess various NPS (Nessi, 2013; Bizcocho and Llatas, 2019). The system boundaries included the downstream and upstream processes for each CW fraction generated. However, due to the application of the zero-burden assumption, the upstream processes were excluded from the system boundaries of NPS and appear as prevented loads in the PS as shown in Fig. 1.

4.5.1.1. CW analysed Two types of CW were identified (European Commission, 2018b): (i) (mirror) hazardous (MH) CW; and (ii) (mirror) non-hazardous (MNH) CW (see Table 3). In accordance with 
Table 2

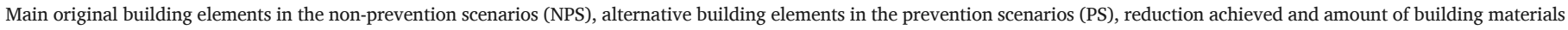
added and avoided (m-M) in PS in each alternative building element, and in the alternative Reference Building (RB).

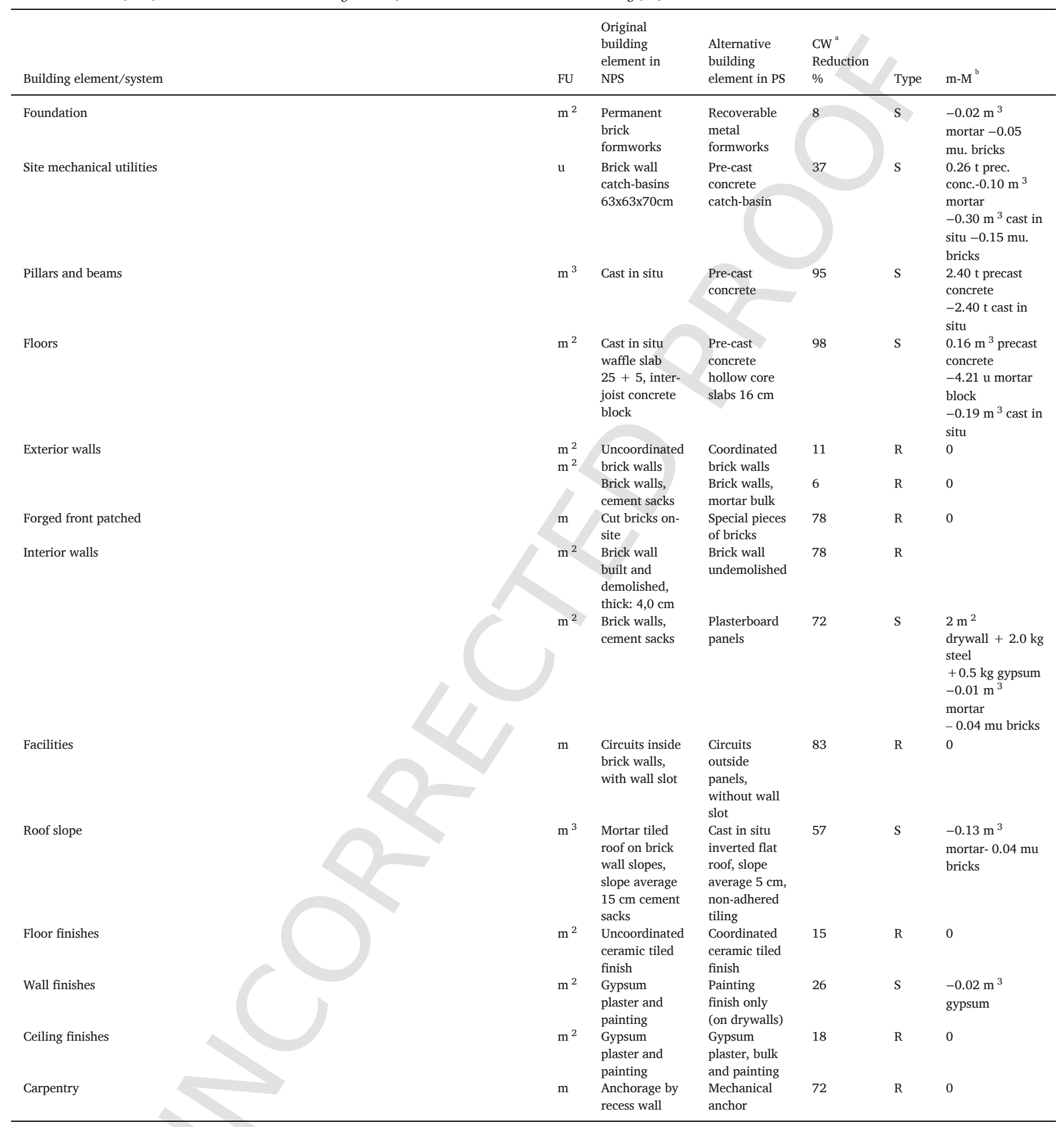




\begin{tabular}{|c|c|c|c|c|c|c|}
\hline Building element/system & FU & $\begin{array}{l}\text { Original } \\
\text { building } \\
\text { element in } \\
\text { NPS }\end{array}$ & $\begin{array}{l}\text { Alternative } \\
\text { building } \\
\text { element in PS }\end{array}$ & $\begin{array}{l}\mathrm{CW}^{\mathrm{a}} \\
\text { Reduction } \\
\%\end{array}$ & Type & $\mathrm{m}-\mathrm{M}^{\mathrm{b}}$ \\
\hline Building $\mathrm{n}$ & $\mathrm{u}$ & $\begin{array}{l}\text { Original } \\
\text { Reference } \\
\text { Building } \\
21,150 \mathrm{~m}^{2}\end{array}$ & $\begin{array}{l}\text { Alternative } \\
\text { Reference } \\
\text { Building } \\
21,150 \mathrm{~m}^{2}\end{array}$ & $57^{c}$ & $\mathrm{R} / \mathrm{S}$ & $\begin{array}{l}5,172 \mathrm{t} \text { precast } \\
\text { concrete } \\
-11424 \mathrm{t} \text { cast in } \\
\text { situ }-972 \mathrm{t} \\
\text { mortar } \\
-1245 \mathrm{t} \text { bricks } \\
+311 \mathrm{t} \text { drywall } \\
-851 \mathrm{t} \text { gypsum } \\
-2292 \mathrm{t} \text { mortar } \\
\text { block }+39 \mathrm{t} \\
\text { steel }\end{array}$ \\
\hline
\end{tabular}

FU: Functional unit; R: Reductive alternative building element; S: Substitute alternative building element; u: unit.

a Reduction by volume obtained from Llatas and Osmani (2016).

b Obtained from BCCA (Andalusian Government, 2017).

c Reduction by mass.

Table 3

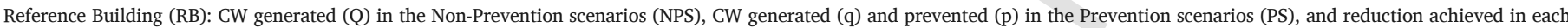
CW fraction.

\begin{tabular}{|c|c|c|c|c|c|c|}
\hline Code European Waste List & Stream of CW & Entry Type & t waste & & & $\mathrm{CW}^{\mathrm{b}}$ Reduction $\%$ \\
\hline & & & $\mathrm{Q}^{\mathrm{a}}$ & $q^{b}$ & $\mathrm{p}^{\mathrm{b}}$ & \\
\hline 170101 & concrete & $\mathrm{MNH}$ & 966.7 & 377.9 & 588.8 & 61 \\
\hline $170102 / 03$ & bricks/tiles & $\mathrm{MNH}$ & 346.6 & 163.0 & 183.6 & 53 \\
\hline 170107 & concrete/ceramics & MNH & 255.0 & 112.9 & 142.1 & 56 \\
\hline $170204 *$ & wood & $\mathrm{MH}$ & 110.3 & 14.4 & 95.9 & 87 \\
\hline 170202 & glass & $\mathrm{MNH}$ & 0.6 & 0.6 & 0.0 & 0 \\
\hline 170203 & plastic & MNH & 0.6 & 0.4 & 0.2 & 29 \\
\hline $170301^{*}$ & bituminous mixt. & $\mathrm{MH}$ & 1.1 & 0.7 & 0.4 & 34 \\
\hline 170401 & copper & $\mathrm{MNH}$ & 2.2 & 1.9 & 0.3 & 10 \\
\hline 170402 & aluminum & $\mathrm{MNH}$ & 1.2 & 1.1 & 0.1 & 5 \\
\hline 170405 & iron and steel & $\mathrm{MNH}$ & 14.7 & 6.3 & 8.4 & 57 \\
\hline 170802 & gypsum-based mat. & $\mathrm{MNH}$ & 20.6 & 5.4 & 15.2 & 74 \\
\hline 170904 & mixed waste & $\mathrm{MNH}$ & 113.5 & 53.8 & 59.7 & 53 \\
\hline 150101 & paper/cardboard & MNH & 14.4 & 3.7 & 10.7 & 74 \\
\hline 150102 & plastic packaging & $\mathrm{MNH}$ & 16.9 & 7.1 & 9.9 & 58 \\
\hline 150103 & wooden packaging & $\mathrm{MNH}$ & 591.2 & 306.0 & 285.2 & 48 \\
\hline $150110 *$ & metallic packaging & MH & 6.0 & 2.3 & 3.7 & 62 \\
\hline 150106 & mixed packaging & MNH & 11.2 & 2.9 & 8.3 & 74 \\
\hline Total CW (t) & & & $2,472.7$ & $1,060.4$ & $1,412.3$ & 57 \\
\hline Total CW per GFA ( $\mathrm{t} / \mathrm{m} 2)$ & & & 0.117 & 0.051 & 0.066 & \\
\hline
\end{tabular}

MH: (mirror) hazardous (marked with an asterisk); MNH: (mirror) non- hazardous

a Obtained from Llatas (2011).

b Obtained from Llatas and Osmani (2016).

Spanish legislation (Spanish Government, 2008, 2015), each type of CW must be managed differently. This study focused on MNH CW, by analysing 10 main fractions shown in Table 4 . The wooden pallets were considered re-used, since they are usually removed by the material suppliers, and therefore remain outside the scope of the study.

4.5.1.2. Scenarios analysed For each CW fraction, four management scenarios were assessed:

- $\mathrm{PS}_{1}$, of prevention, which reduces CW at source by applying the alternative building elements shown in Table 2, and the amount of CW generated $(\mathrm{q})$ is recycled in the recycling plant closest to the RB.

- $\mathrm{PS}_{2}$, of prevention, equal to $\mathrm{PS}_{1}$, with the use of recycled vs. unrecycled products in alternative building elements: in this case, recycled steel in plasterboard partitions.

- $\mathrm{NPS}_{1}$, of disposal, in which the amount of CW generated (Q) is deposited in the landfill closest to the RB.

- $\mathrm{NPS}_{2}$, of recycling, in which the amount of CW generated $(\mathrm{Q})$ is recycled at the recycling plant closest to the RB.

\subsubsection{Generic impact factors (F)}

4.5.2.1. Material manufacturing subsystem and waste management subsystem To obtain " $F$ ", both the Material Manufacturing Subsystem (material manufacturers, suppliers), and the Waste Management Subsystem (recycling plants, landfills) in the study area of Seville were analysed in Bizcocho (2014) and in Bizcocho and Llatas (2019). The analysis applied the principle of proximity and located the facilities to obtain the distances with respect to the RB (see Fig. 2).

4.5.2.2. LCI To create the LCI, the LCA modelling assumptions considered in Bizcocho (2014) were further developed in Bizcocho and Llatas (2019). The upstream $(\alpha)$ and downstream $(\Omega)$ processes were analysed. One of the main difficulties involved obtaining primary data from companies, and therefore it was necessary to finally resort to background data from databases, such as Ecoinvent v1.2 (Frischknecht et al., 2005), and the literature. For example, processes related to the recycling of inert $\mathrm{CW}$ of a stony nature were 
Table 4

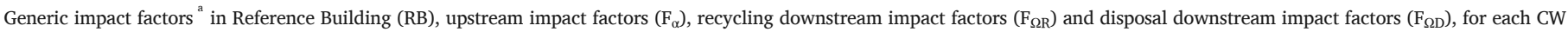
fraction.

\begin{tabular}{|c|c|c|c|c|c|c|c|c|c|c|c|c|c|c|c|c|c|c|c|c|}
\hline \multirow{3}{*}{$\begin{array}{l}\text { Code European } \\
\text { Waste List } \\
170101 \\
\text { concrete }\end{array}$} & \multicolumn{3}{|c|}{$\begin{array}{c}\text { AP } \\
\text { (kg SO2 eq)/ } \\
\text { t waste }\end{array}$} & \multicolumn{3}{|c|}{$\begin{array}{c}\text { EP } \\
\text { (kg PO4eq)/ } \\
\text { t waste }\end{array}$} & \multicolumn{3}{|c|}{$\begin{array}{c}\text { GWP } \\
\text { (kg CO2 eq)/ } \\
\text { t waste }\end{array}$} & \multicolumn{3}{|c|}{$\begin{array}{c}\text { ODP } \\
\text { (kg CFC-11 eq)/ } \\
\text { t waste }\end{array}$} & \multicolumn{3}{|c|}{$\begin{array}{c}\text { HTP } \\
\text { (kg 1,4-DB eq)/ } \\
\text { t waste }\end{array}$} & \multicolumn{3}{|c|}{$\begin{array}{c}\text { POP } \\
\text { (kg C2H4) / } \\
\text { t waste }\end{array}$} & \multicolumn{2}{|c|}{$\begin{array}{c}\text { CED } \\
\text { (MJ eq)/ } \\
\text { t waste }\end{array}$} \\
\hline & $\mathrm{F}_{\alpha}$ & $F_{\Omega R}$ & $F_{\Omega D}$ & $F_{\alpha}$ & $F_{\Omega R}$ & $F_{\Omega D}$ & $F_{\alpha}$ & $F_{\Omega R}$ & $F_{\Omega D}$ & $\mathrm{~F}_{\alpha}$ & $F_{\Omega R}$ & $F_{\Omega D}$ & $F_{\alpha}$ & $F_{\Omega R}$ & $\mathrm{~F}_{\Omega \mathrm{D}}$ & $F_{\alpha}$ & $\mathrm{F}_{\Omega \mathrm{R}}$ & $F_{\Omega D}$ & $\mathrm{~F}_{\alpha}$ & $F_{\Omega R} \quad F_{\Omega D}$ \\
\hline & $-2.1 E-01$ & $-5.3 E-03$ & $32.0 \mathrm{E}-02$ & $-3.1 E-02$ & $-4.1 E-04$ & $4.3 \mathrm{E}-03-1$ & $-1.2 E+02-$ & $-7.6 \mathrm{E}-01$ & $2.7 E+00-$ & $-3.7 E-06-$ & $-6.2 E-08$ & $3.5 E-07-6$ & $-6.3 E+00$ & $-9.7 E-02$ & $1.6 \mathrm{E}+00-7$ & $-7.3 E-03$ & $-1.8 \mathrm{E}-045$ & $5.1 E-04-5$ & $-5.6 E+02-1$ & $-1.7 E+014.0 E+01$ \\
\hline $\begin{array}{l}170102 / 03 \\
\text { bricks-tiles }\end{array}$ & $-5.1 \mathrm{E}-01$ & $-4.3 E-03$ & $32.0 \mathrm{E}-02$ & $-6.2 \mathrm{E}-02$ & $-2.8 \mathrm{E}-04$ & $4.3 \mathrm{E}-03-2$ & $-2.1 E+02-$ & $-6.1 \mathrm{E}-01$ & $2.8 \mathrm{E}+00$ & $-1.5 E-05$ & $-4.6 \mathrm{E}-08$ & 3.5E-07-1 & $-1.7 E+01$ & $-3.1 E-02$ & $1.6 E+00-3$ & $-3.7 E-02$ & $-1.4 \mathrm{E}-045$ & $5.3 \mathrm{E}-04-2$ & $-2.7 E+03-1$ & $-1.4 E+014.1 E+01$ \\
\hline $\begin{array}{l}170107 \\
\text { mix conc.-ceram. }\end{array}$ & $-3.1 \mathrm{E}-01$ & $-3.2 \mathrm{E}-03$ & $32.0 \mathrm{E}-02$ & $-4.1 E-02$ & $-8.4 \mathrm{E}-05$ & $4.3 \mathrm{E}-03-1$ & $-1.5 E+02-$ & $-4.7 \mathrm{E}-01$ & $2.8 \mathrm{E}+00-$ & $-7.4 E-06-$ & $-3.1 E-08$ & $3.5 E-07-5$ & $-9.9 E+00$ & 3.7E-02 & $1.6 \mathrm{E}+00-1$ & $-1.7 E-02$ & $-1.1 \mathrm{E}-045$ & $5.3 \mathrm{E}-04-1$ & $-1.3 E+03-1$ & $-1.2 E+014.1 E+01$ \\
\hline $\begin{array}{l}170401 \\
\text { copper }\end{array}$ & $-1.4 E+02-$ & $-3.0 \mathrm{E}+01$ & $18.5 \mathrm{E}-02$ & $-4.0 E+00-$ & $-2.0 \mathrm{E}+00$ & $1.4 \mathrm{E}-02-1$ & $-1.7 E+03-6$ & $-6.8 E+01$ & $1.5 E+01-$ & $-1.3 E-04$ & $-4.8 \mathrm{E}-05$ & $1.4 \mathrm{E}-06-\varepsilon$ & $-8.8 \mathrm{E}+04$ & $-1.1 E+04$ & $6.0 \mathrm{E}+00$ & $-5.1 E+00$ & $-9.3 \mathrm{E}-012$ & $2.9 \mathrm{E}-03-3$ & $-3.1 E+04-4$ & $-4.8 E+032.5 E+02$ \\
\hline $\begin{array}{l}170402 \\
\text { aluminum }\end{array}$ & $-3.7 E+01-$ & $-4.7 E+01$ & $8.5 \mathrm{E}-02$ & $-3.3 E+00$ & $-4.2 \mathrm{E}+00$ & $1.4 \mathrm{E}-02-8$ & $-8.1 E+03-1$ & $-1.0 E+041$ & $1.5 E+01$ & $-4.9 E-04-$ & $-5.7 \mathrm{E}-04$ & $1.4 \mathrm{E}-06-3$ & $-3.7 E+04$ & $-5.2 E+04$ & $6.0 E+00=$ & $-3.2 E+00$ & $-4.3 E+002$ & $2.9 \mathrm{E}-03-1$ & $-1.3 E+05-1$ & $-1.6 E+052.5 E+02$ \\
\hline $\begin{array}{l}170405 \\
\text { steel }\end{array}$ & $-4.7 E+00-3$ & $-3.5 E+00$ & $4.3 E-02$ & $-1.0 E+00$ & $-9.1 \mathrm{E}-01$ & $8.2 \mathrm{E}-03-1$ & $-1.4 E+03-1$ & $-1.1 E+03$ & $6.2 E+00$ & $-5.2 \mathrm{E}-05-$ & $-4.0 \mathrm{E}-06$ & $7.0 \mathrm{E}-07-5$ & $-5.8 \mathrm{E}+02$ & $1.5 \mathrm{E}+02$ & $1.1 E+01-7$ & $-7.9 E-01$ & $-8.4 \mathrm{E}-011$ & $1.2 \mathrm{E}-03-2$ & $-2.2 E+04-1$ & $-1.3 E+041.0 E+02$ \\
\hline $\begin{array}{l}170802 \\
\text { gypsum }\end{array}$ & $-1.0 \mathrm{E}+00$ & $-1.8 \mathrm{E}-01$ & $2.7 E+01$ & $-1.6 \mathrm{E}-01-$ & $-4.4 \mathrm{E}-02$ & $2.1 \mathrm{E}-01-3$ & $-3.4 \mathrm{E}+02$ & $1.9 \mathrm{E}+02 \mathrm{~S}$ & $9.4 \mathrm{E}+01$ & $-3.6 \mathrm{E}-05-$ & $-6.8 \mathrm{E}-07$ & $7.6 \mathrm{E}-07-4$ & $-4.2 \mathrm{E}+01$ & $-4.9 E+00$ & $7.4 E+01-4$ & $-4.2 E-02$ & $-6.4 \mathrm{E}-031$ & $1.1 \mathrm{E}+00-5$ & $-5.6 \mathrm{E}+03-2$ & $-2.6 \mathrm{E}+031.1 \mathrm{E}+02$ \\
\hline $\begin{array}{l}150101 \\
\text { paper }\end{array}$ & $-2.7 E+00-$ & $-2.9 E+00$ & $1.9 \mathrm{E}-01$ & $-9.5 \mathrm{E}-01-$ & $-7.2 \mathrm{E}-012$ & $2.7 E+00-5$ & $-5.9 E+02$ & $2.6 \mathrm{E}+03$ & $1.6 \mathrm{E}+03-$ & $-8.0 E-05$ & $-3.1 \mathrm{E}-05$ & $1.1 \mathrm{E}-06-1$ & $-1.6 \mathrm{E}+02$ & $-8.5 E+01$ & $1.2 \mathrm{E}+02-1$ & $-1.4 \mathrm{E}-01$ & $-1.1 \mathrm{E}-013$ & $3.3 \mathrm{E}-01-2$ & $-2.4 E+04-3$ & $-3.9 E+042.3 E+02$ \\
\hline $\begin{array}{l}170203 / 150102 \\
\text { plastic }\end{array}$ & $-1.0 E+01-$ & $-2.5 E+00$ & $5.3 E-02$ & $-7.8 \mathrm{E}-01-$ & $-2.1 \mathrm{E}-015$ & $5.2 E+00-2$ & $-2.5 E+03-6$ & $-6.9 E+02$ & $1.0 E+02-$ & $-2.7 \mathrm{E}-05$ & $1.3 \mathrm{E}-05$ & $8.9 \mathrm{E}-07-2$ & $-2.1 E+02$ & $1.9 \mathrm{E}+01$ & $2.3 E+03-5$ & $-5.1 \mathrm{E}-01$ & $-1.4 E-012$ & $2.1 E-02-5$ & $-9.2 E+04-2$ & $-2.9 E+041.2 E+02$ \\
\hline $\begin{array}{l}170904 / 150106 \\
\text { mixed waste }\end{array}$ & $-5.1 \mathrm{E}-01$ & $4.9 \mathrm{E}-02$ & $3.8 \mathrm{E}-02$ & $-6.7 E-02$ & $1.5 \mathrm{E}-02$ & $1.2 \mathrm{E}-02-1$ & $-1.8 E+02$ & $6.6 \mathrm{E}+00$ & $5.1 \mathrm{E}+00$ & $-9.2 E-06$ & $7.9 \mathrm{E}-07$ & $6.0 \mathrm{E}-07-2$ & $-2.9 \mathrm{E}+01$ & $7.8 \mathrm{E}+01$ & $.7 .6 E+01-2$ & $-2.9 \mathrm{E}-02$ & $1.3 \mathrm{E}-03 \mathrm{~g}$ & $9.8 \mathrm{E}-04-3$ & $-3.0 \mathrm{E}+031$ & $1.0 E+027.9 E+01$ \\
\hline
\end{tabular}

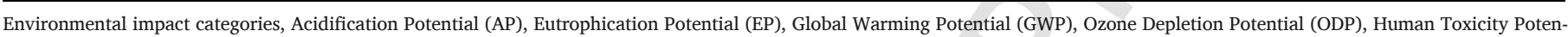
tial (HTP), Photochemical Oxidation Potential (POP), Cumulative Energy Demand (CED)

a Obtained from Bizcocho and Llatas, 2019; and Bizcocho, 2014; $\square$ maximum value in each column; $\square$ minimum value in each column

not available in the Ecoinvent v1.2 databases, for which the bibliography was used, and data was obtained as the average of other related studies (Bizcocho and Llatas, 2019).The downstream $(\Omega)$ processes regarding $\mathrm{NPS}_{1}$ included on-site storage, transport to disposal facility, and landfill. The downstream $(\Omega)$ processes regarding $\mathrm{NPS}_{2}$ depended on the type of fraction: (i) in the case of concrete/ceramic, gypsum, and plastic, this involved on-site storage, transport to their respective recycling facility, and treatment (for recycled aggregates, for recycled plaster, and for secondary plastic); (ii) in the case of metals and paper, this involved on-site storage, transport to their respective recycling facility, and treatment (for secondary metals, for secondary paper pulp); (iii) in the case of mixed wastes: on-site storage, transport to sorting plant, transport to disposal facility, and landfill.Various assumptions were made: (i) for on-site storage, $8 \mathrm{~m}^{3}$ tanks were used; (ii) for transport, 16-ton and 32-ton trucks were employed in the case of transferring from the recovery plant to the recycling plant to optimise the transport; (iii) for landfill, the unit processes were taken from Ecoinvent v1.2 (Frischknecht et al., 2005) for each type of waste; (iv) for recycling, a few unit processes were obtained from companies, and were completed with Ecoinvent v1.2 (Frischknecht et al., 2005) and the literature (Bizcocho and Llatas, 2019).The upstream $(\alpha)$ processes included: production, transport, and construction. Data was obtained for each type of waste. Several assumptions were made: (i) for production, use of local materials; (ii) for transport, 16-ton trucks; (iii) for construction, energy consumption was estimated according to Kellenberger et al. (2007) (Bizcocho and Llatas, 2019). Likewise, to obtain the upstream impact factor $(\mathrm{F} \alpha)$ of the avoided building materials $(-\mathrm{M}$ in Table 2, e.g., cast-in-situ concrete) and added building materials $(+\mathrm{m}$ in Table 2, e.g., precast concrete), Ecoinvent v1.2 (Frischknecht et al., 2005) and Environmental Product Declarations (EPDs) (e.g., EPD International, 2020) were considered.Other assumptions (Bizcocho and Llatas, 2019) were:

- Transport was modelled considering the type of lorry, the load, and the distance covered, as were the routes along which the lorry was unloaded, with lower fuel consumption (European Commission-JRC-IES, 2011a).

- In $\mathrm{NPS}_{2}$, the primary products that were not consumed thanks to recycling were considered.

- Environmental burdens due to capital goods, such as infrastructure, machinery, and lorries, were not considered.
4.5.2.3. LCIA The generic impacts (F) were obtained for 1 ton of each CW fraction using SimaPro 7.1 (Table 4).

4.5.2.4. Analysis of results According to Table 4, all instances of generic " $F$ " were positive, except for upstream impact factor $(F \alpha)$, which removes upstream loads of avoided wastes and building materials, and for certain fractions for the downstream impact factor $\left(\mathrm{F}_{\Omega}\right)$ in the recycling option $\left(\mathrm{F}_{\Omega \mathrm{R}}\right)$, which eliminates the loads of materials to be replaced, according to the "avoided load" approach (Finnveden et al., 2009). Moreover, the values of "F $\alpha$ " were generally much higher than those of " $\mathrm{F}_{\Omega}$ ", thereby indicating the considerable role played in PS.All scenarios contemplated sorting on site, before transporting the $\mathrm{CW}$ to the recycling plant or landfill. However, as was observed on the working site, even if CW is separated on site, a mixed CW fraction was inevitably generated. Mixed packaging waste was not separated on site and was managed together with mixed waste. In NPS 2 , the mixed fraction was transported to a sorting plant where it should have been separated, and each fraction recycled. However, in practice, this fraction is often contaminated and has low potential for recycling, in such a way that it is usually rejected and taken to landfill for disposal. Therefore, $\mathrm{NPS}_{2}$ considered the disposal of the mixed fraction. This greater number of processes (transport, triage, etc.) in $\mathrm{NPS}_{2}$ for the mixed fraction resulted in a higher impact factor for recycling compared to $\mathrm{NPS}_{1}$, as shown in Table 4.

\subsubsection{Environmental impacts in scenarios}

4.5.3.1. Environmental impacts Finally, once the variables of the model $\left(\mathrm{Q}, \mathrm{q}, \mathrm{p}, \mathrm{m}, \mathrm{M}, \mathrm{F}_{\alpha}, \mathrm{F}_{\Omega}\right.$ ) were known, the environmental impact was quantified using Eq. (3) and Eq. (4) for each CW fraction, for each type of scenario, and for the entire building. Fig. 3 shows the impact per category. Fig. 4 shows the impact with respect to the most unfavourable scenario, $\mathrm{NPS}_{1}$, for the entire RB.

4.5.3.2. Analysis of results The model enabled the most favourable scenarios to be identified in terms of categories and types of CW, and in terms of simulating alternatives. Fig. 3 a-f, h) shows how PS 1 presents the most favourable scenario for all $\mathrm{CW}$ fractions and categories, but with certain exceptions. In certain types of $\mathrm{CW}$, such as metals and paper, $\mathrm{NPS}_{2}$ was more beneficial than $\mathrm{PS}_{1}$ in several impact categories. Moreover, steel prevention was the worst scenario in terms of ODP, CED, and GWP vs. recycling. The reason is that for $\mathrm{NPS}_{2}$, replaced materials that eliminate loads from the system were considered, while this strategy was not applied to the new materials added $(+\mathrm{m})$ in $\mathrm{PS}_{1}$ as a 


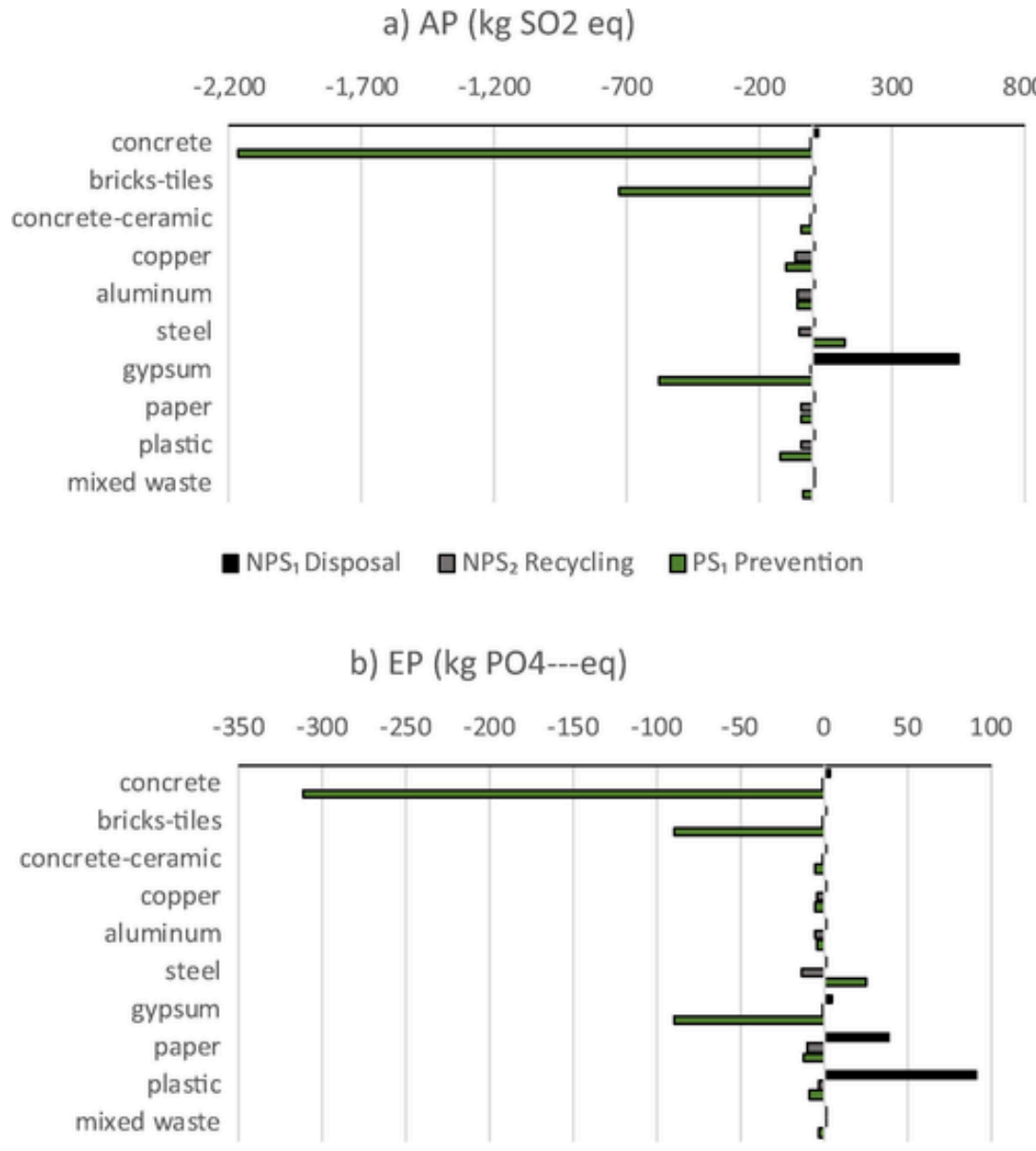

NPS $S_{1}$ Disposal $\quad$ aNPS $S_{2}$ Recycling aPS Prevention

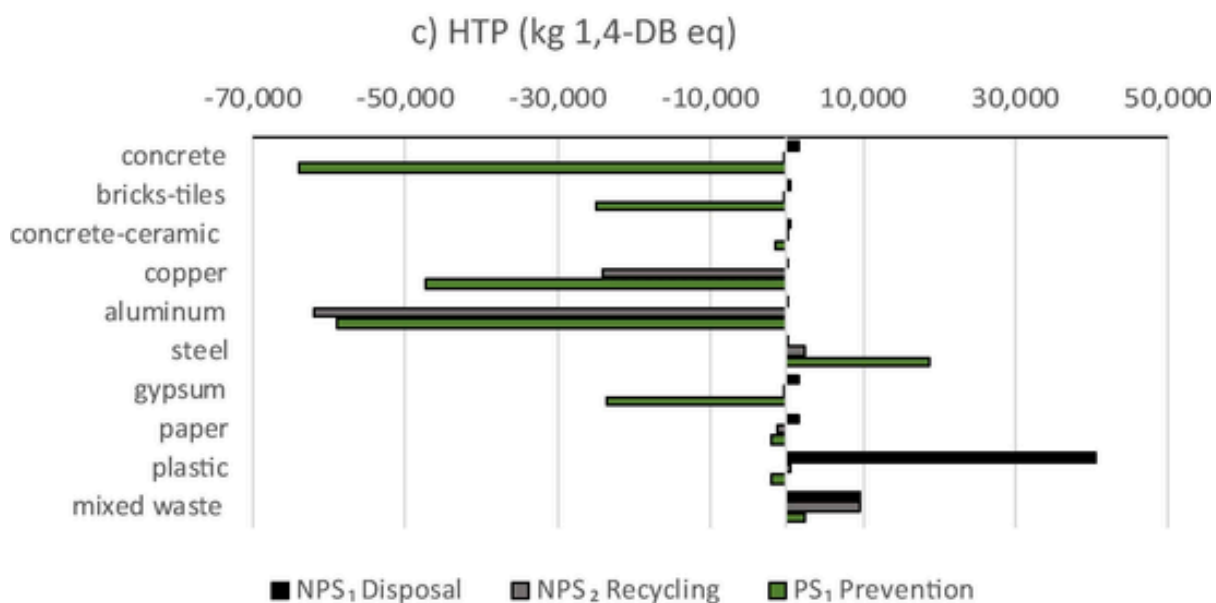

Fig. 3. Environmental impacts in the Reference Building (RB) by category. (a-f, h) PS ${ }_{1}$ with non-recycled steel (m). (g, i) PS 2 with recycled steel (m).

consequence of the substitute building elements. In order not to penalise the $\mathrm{PS}_{1}$, the model allowed a greater benefit to be attained in this scenario by using recycled materials instead of natural materials in the substitute elements. For example, in the case study, if the $39 \mathrm{t}$ of non-recycled steel added by plasterboard partitions (see Table 2) in $\mathrm{PS}_{1}$ were instead recycled steel, then in $\mathrm{PS}_{2}$, the prevention for steel would have been more favourable vs. recycling, as shown Fig. $3 \mathrm{~g}$, i). On the other hand, NPS ${ }_{1}$ was the worst scenario, with certain exceptions. For example, in the case of GWP, for gypsum and paper, the worst scenario was $\mathrm{NPS}_{2}$, since the $\mathrm{CO}_{2}$ (eq) emissions from recycling $\left(\mathrm{F}_{\Omega \mathrm{R}}\right)$ these materials were higher than those due to their disposal $\left(\mathrm{F}_{\Omega \mathrm{D}}\right)$, as shown in Table 4. The model also detected the most contaminated scenario of CW in each impact category: gypsum disposal for AP and POP; plastic disposal for EP and HTP; paper recycling for GWP; concrete disposal for ODP (if $\mathrm{PS}_{2}$ ); and the most energy-consuming waste, concrete disposal for CED (if $\mathrm{PS}_{2}$ ).The total calculation of the impact of all the $\mathrm{CW}$ in the alternative $\mathrm{RB}$ leads to the conclusion that the most favourable scenario for all impact categories is indeed preven- 


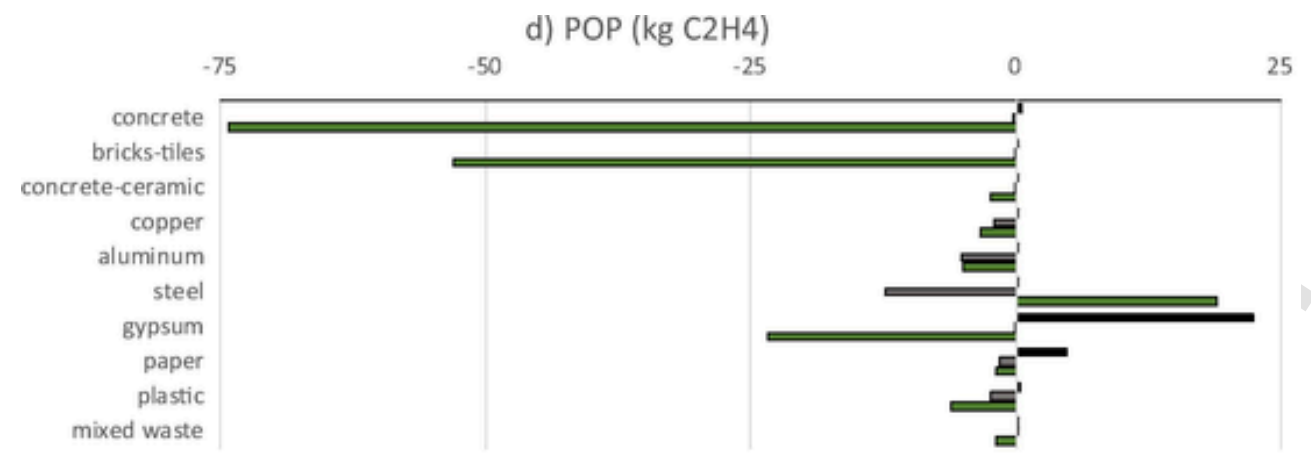

-NPS, Disposal aNPS Recycling uPS, Prevention

e) ODP ( $k g$ CFC-11 eq)

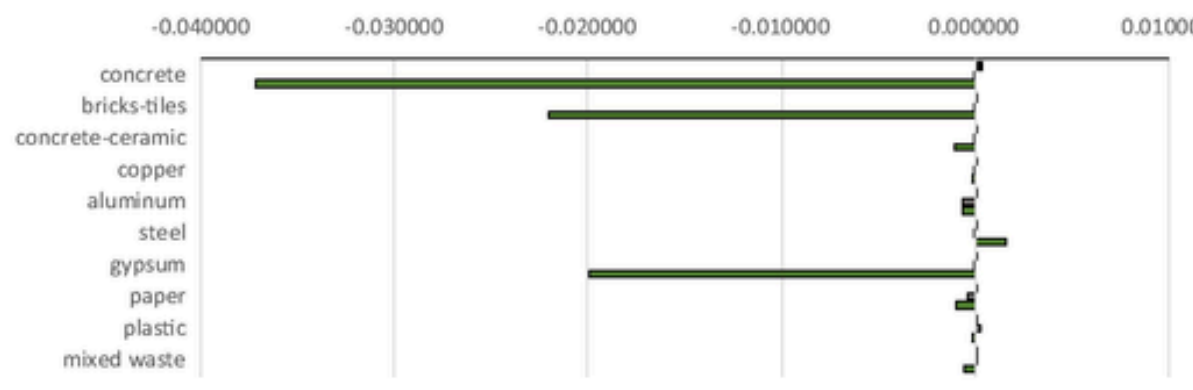

- NPS, Disposal aNPS, Recycling aPS, Prevention

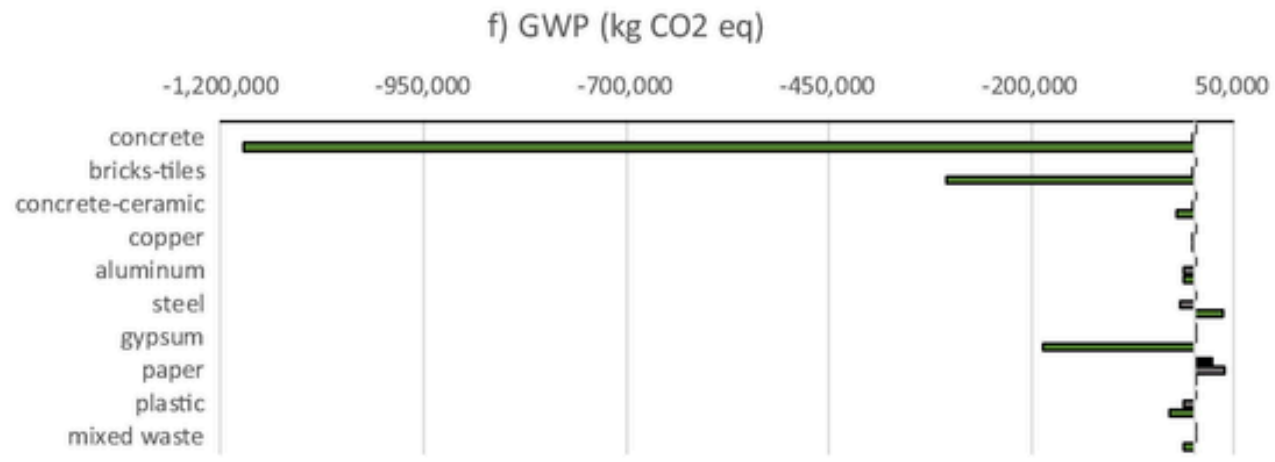

- NPS, Disposal aNPS, Recycling aPS, Prevention

g) GWP (kg CO2 eq)

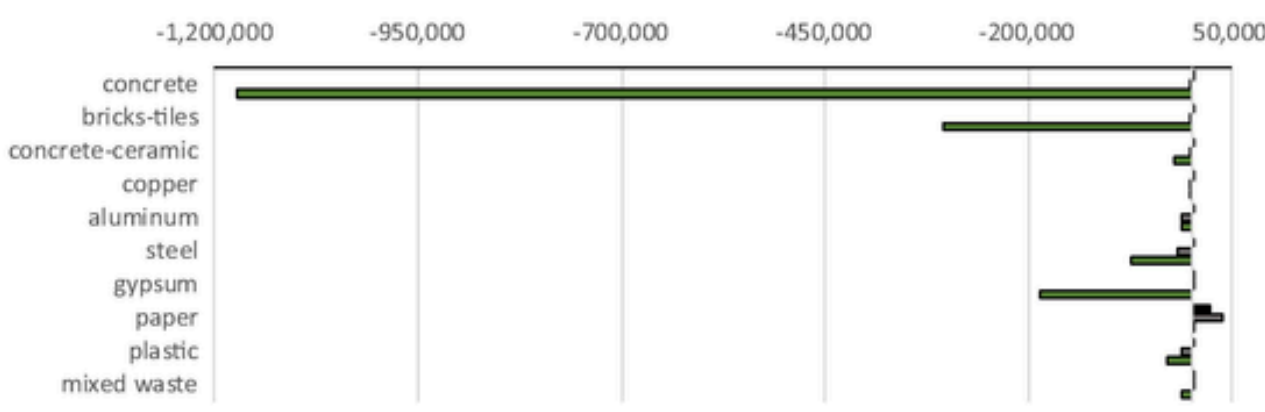

NPS $S_{1}$ Disposal $\square N P S_{2}$ Recycling $\quad P^{2} S_{2}$ Prevention

tion $\left(\mathrm{PS}_{1}\right)$, followed by recycling (NPS $)$, and finally, disposal $\left(\mathrm{NPS}_{1}\right)$, as shown in Fig. 4. This is due to the fact that the reduction of building materials $(-11,262 \mathrm{t}=\mathrm{m}-\mathrm{M})$ and waste materials
$(-1,412 \mathrm{t}=\mathrm{q}-\mathrm{Q})$ in the $\mathrm{RB}$ exerted a major effect on reducing impact in PS, thanks to the elimination of their upstream processes, which were much higher than the loads of the downstream processes of the 

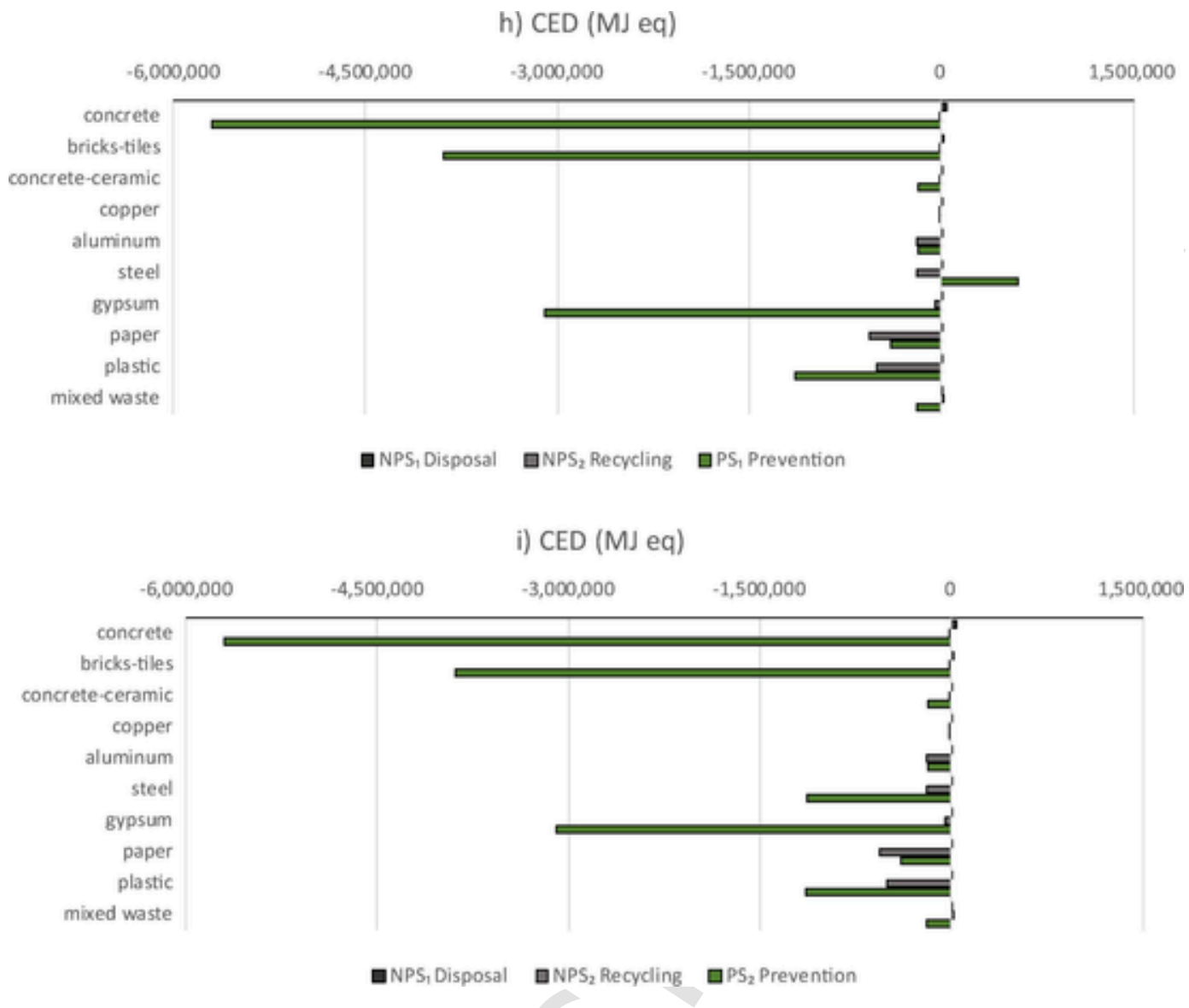

Fig. 3. Continued

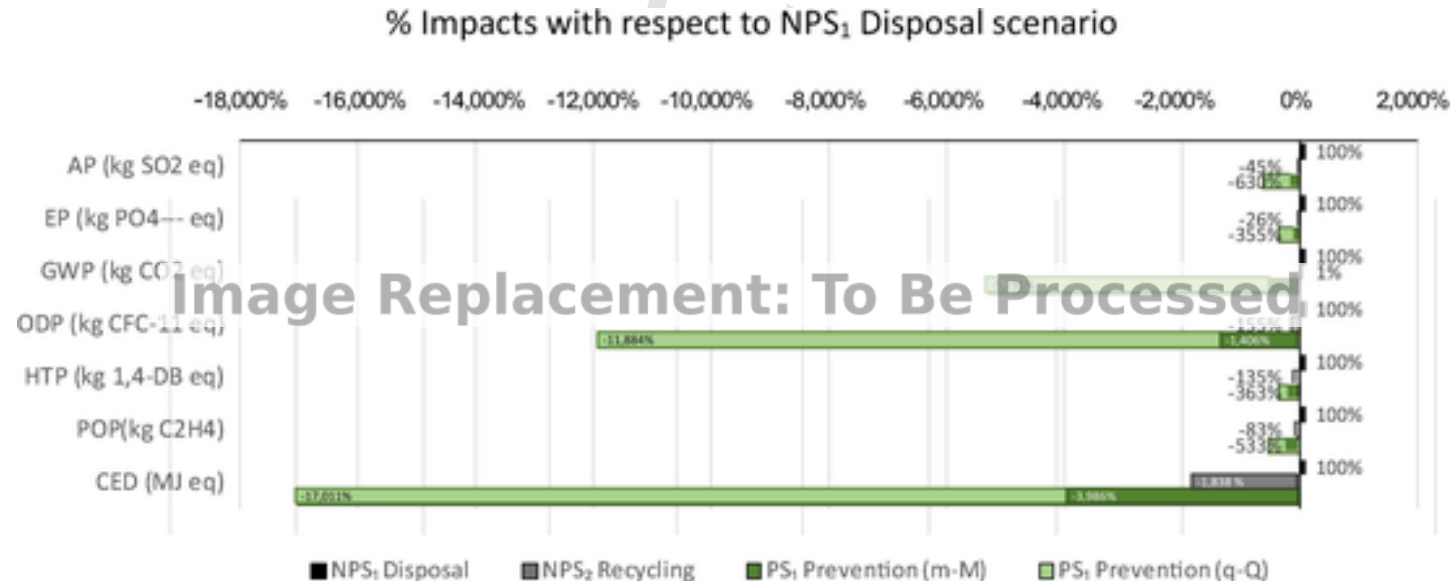

Fig. 4. Environmental impacts in the Reference Building (RB). Incidence of building materials added and avoided ( $\mathrm{m}-\mathrm{M})$, and waste materials added and avoided ( $\mathrm{q}-\mathrm{Q})$ in $\mathrm{PS}{ }_{1}$.

CW. Therefore, the application of the CW reduction strategies in the RB would have led to a reduction of between 4.6 (in EP) and 171.1 (in CED) times the impact caused in $\mathrm{NPS}_{1}$, while $\mathrm{NPS}_{2}$ would only have reduced between 1.0 (in GWP) and 19.4 (in CED) times the impact of NPS . Moreover, the use of re-used and recycled materials in the alternative building elements in $\mathrm{PS}_{2}$ could achieve even greater environmental benefits in PS.

\section{Discussion}

\subsection{Validation}

The model enables the comparison of PS vs. NPS of CW management in buildings, by obtaining their environmental impact, which has successfully filled a research gap in the literature. The variables are obtained using previously validated methods: "Q", as described in Llatas (2011); "q" and "p", as described in Llatas and Osmani, (2016); "M" and "m", from BCCA (Andalusian Government, 2017); and both the generic impact factors and overall impact, through LCA standards (ISO, 2006a; 2006b) as described in Bizcocho and Llatas (2019), which deal with the main methodological issues for the inclusion of PS in the CW management system of buildings. Although the model seems to be a suitable approach, further verification in other case studies is needed. 


\subsection{Limitations and future developments}

A main limitation in addressing the LCA of waste management including prevention, with respect to the "traditional" LCA, is the large amount of data involved, due to the necessary inclusion of upstream processes. The literature assumes that the LCA of buildings can be highly complex, especially during the LCI phase (Malmqvist et al., 2011), where simplifications can be performed without the results being substantially affected (Kellenberger and Althaus, 2009; Zabalza Bribián et al., 2009; John, 2012; Soust-Verdaguer et al., 2016). This study has employed the following simplification: generic impact factors of an Integrated Urban System of Buildings are used, instead of specific impact factors quantified for each building, to enable its application in other buildings. This strategy has also been incorporated in other tools in the field of MSW, such as WARM (EPA, 2019). Moreover, the complexity of LCA-based models in buildings can be overcome with the application of technologies that are capable of handling large amounts of data and of automating calculations, such as Building Information Modelling (BIM) (e.g., Revit, Allplan, and Archicad). The BIM methodology also enjoys the advantage of being focused on the building design process, a crucial phase for the prevention of $\mathrm{CW}$ production and environmental impact.

The present study introduced a case study, for which the principal difficulty lies in obtaining primary data. Further developments should therefore address more assessments that include not only different building typologies and contexts, but also other PS and NPS. Moreover, sensitivity and uncertainty analyses should be undertaken in order to test the accuracy of the results.

Finally, the Joint Research Centre on behalf of the European Commission (European Commission-JRC-IES, 2011b), states that all the upstream processes should be included in the system boundaries except when these processes exert very little effect on the results. This study included not only the upstream of the processes added or avoided by the waste materials ( $\mathrm{q}-\mathrm{Q}$ ), but also those added and avoided by the substitute building materials (m-M) during the construction stage. However, future developments may consider the effect of $\mathrm{CW}$ prevention in other building life cycle stages beyond the system boundaries of this study, such as the use and end-of-life stages. The usefulness of the model in the use phase lies, for example, in evaluating the benefit achieved in the PS from the use of alternative materials to repair and replace building elements. Materials that require a high degree of maintenance (e.g., steel), could be less beneficial with respect to other materials (e.g., concrete) during the use phase. In the end-of-life phase, the model can be useful for the quantification of the benefits of a PS by using alternative materials that can be re-used, recycled, and even upcycled. Likewise, the recoverability of building materials at the end of their life could be analysed. For example, dry anchors would favour reusability over wet anchored materials. In the case study, the alternatives introduced non-adhered materials (such as drywalls) and low-maintenance materials (such as precast concrete), which anticipate low maintenance during the use phase, and a high recoverability of materials at the end-of-life stage of the building. This, in turn, contributes towards approaching reversibility in building design and Circular Economy challenges in construction, such as those of the EU (European Environment Agency, 2020).

\section{Conclusions}

Although CW prevention is the first and foremost principle of any CW management system, research efforts in recent decades have largely been focused on discovering the environmental benefits of non-prevention, that is, recycling vs. disposal, rather than revealing the environmental benefits of prevention vs. non-prevention. This study developed a simplified model to ascertain the impact of CW prevention in buildings. Through case study verification, it was shown that CW prevention presents the most favourable scenario, since it allows a poten- tial reduction of up to 4.6 (GWP) and 171.1 (CED) times the impact caused by disposal; and up to 1.7 (GWP) and 8.3 (CED) times those of the recycling. The model is based on previously validated methods and can be implemented in other Urban Systems of Buildings at other locations, by obtaining generic impact factors of their Material Manufacturing Subsystem and Waste Management Subsystem in other reference buildings. Furthermore, this model can provide a useful tool for decision-making in the integration of CW prevention strategies during the building design stages, thereby contributing towards the challenge of Waste Prevention and Circular Economy Strategies. Finally, the knowledge provided together with the results obtained can help professionals and policymakers to include effective CW prevention measures in Waste Prevention Plans and Programs.

\section{Declaration of Competing Interest}

The authors declare that they have no known competing financial interests or personal relationships that could have appeared to influence the work reported in this paper.

\section{Acknowledgements}

The authors are grateful to the Consejería de Vivienda y Ordenación del Territorio de la Junta de Andalucía for having subsidised the Research Project "Construction Waste Reduction in the Design and Construction of Dwellings in Andalusia" (Andalusian Government, 2020) and also to the Spanish Ministry of the Economy for supporting the research project entitled "Development of a unified tool for the quantification and reduction of environmental, social and economic impact of life cycle buildings in Building Information Modelling (BIM) platforms" (ref. BIA2017-84830-R) (Spanish Government, 2018). The authors also thank the companies and individuals involved in this case study for their help and support.

\section{Appendix A. Supplementary material}

Supplementary data to this article can be found online at https://doi. org/10.1016/j.wasman.2021.03.047.

\section{References}

Andalusian Government, 2017. BCCA (Base de Costes de la Construcción de Andalucía. Consejería de Vivienda y Ordenación del Territorio de la Junta de Andalucía, Seville, Spain. http://www.juntadeandalucia.es/ (accessed 17 February 2021; currently only in Spanish).

Andalusian Government, 2020. Grants for research on Housing and Architecture. 2009 Grant Call. Waste reduction in the design and construction of dwellings in Andalusia, Spain.https://www.juntadeandalucia.es/organismos/ fomentoinfraestructurasyordenaciondelterritorio/areas/vivienda-rehabilitacion/ planes-instrumentos/paginas/proyecto-rcds.html/ (accessed 17 February 2021; currently only in Spanish).

Bahramian, M., Yetilmezsoy, K., 2020. Life cycle assessment of the building industry: an overview of two decades of research (1995-2018). Energy Build.. doi:10.1016/ j.enbuild.2020.109917.

Balazs, S., Antonini, E., Tarantitni, M., 2001. Application of life cycle assessment (LCA) methodology for valorization of building demolition materials and products. SPIE Int. Soc. Opt. Eng. 4193, 382-390. doi:10.1117/12.417284.

Bizcocho, N., 2014. Aplicación del Análisis de Ciclo de Vida a la gestión de los Residuos de Construcción (Application of the Life Cycle Assessment to the management of Construction Waste). Ph.D Thesis. University of Seville, Spain. https://idus.us.es/handle/ 11441/56324/ (accessed 17 February 2021; currently only in Spanish).

Bizcocho, N., Llatas, C., 2019. Inclusion of prevention scenarios in LCA of construction waste management. Int. J. Life Cycle Assess. 24 (3), 468-484. doi:10.1007/ s11367-018-1462-8.

Blengini, G.A., 2009. Life cycle of buildings, demolition and recycling potential: a case study in Turin. Italy. Build. Environ. 44 (2), 319-330. doi:10.1016/ j.buildenv.2008.03.007.

Blengini, G.A., Garbarino, E., 2010. Resources and waste management in Turin (Italy): the role of recycled aggregates in the sustainable supply mix. J Clean Prod 18 (10-11), 1021-1030. doi:10.1016/j.jclepro.2010.01.027.

Bossink, B.A.G., Brouwers, H.J.H., 1996. Construction waste: quantification and source evaluation. J. Constr. Eng. Manage. ASCE 122 (1), 55-60.

Bovea, M.D., Powell, J.C., 2016. Developments in life cycle assessment applied to evaluate the environmental performance of construction and demolition wastes. Waste Manage. 50, 151-172. doi:10.1016/j.wasman.2016.01.036. 
Butera, S., Christensen, T.H., Astrup, T.F., 2015. Life cycle assessment of construction and demolition waste management. Waste Manage. 44, 196-205. doi:10.1016/ j.wasman.2015.07.011.

CGATE, CSCAE, 2020. Consejo General de la Arquitectura Técnica de España (CGATE), Consejo Superior de Colegios de Arquitectos de España (CSCAE). Ratios nacionales. Generación de residuos de construcción y demolición. http://www.cscae.com/ images/Libro-Ratios-def.pdf/ (accessed 17 February 2021; currently only in Spanish).

Cleary, J., 2010. The incorporation of waste prevention activities into life cycle assessments of municipal solid waste management systems: methodological issues. Int. J. Life Cycle Assess. 15, 579-589. doi:10.1007/s11367-010-0186-1.

Cleary, J., 2014. A life cycle assessment of residential waste management and prevention. Int. J. Life Cycle Assess. 19, 1607-1622. doi:10.1007/s11367-014-0767-5.

Craighill, A., Powell, J., 1999. A lifecycle assessment and evaluation of construction and demolition waste. In: Working Paper - Centre for Social and Economic Research on the Global Environment (WM 99-03), pp. 1-52.

CTE, 2006. Spanish Building Technical Code. Real Decreto 314/2006 17 marzo. https:// www.codigotecnico.org/ (accessed 17 February 2021; currently only in Spanish).

DECCW, 2010. Environmental benefits of recycling. Department of Environment, Climate Change and Water NSW, Sydney. https://www.epa.nsw.gov.au/-/media/epa/ corporate-site/resources/warrlocal/100058-benefits-of-recycling.pdf/ (accessed 17 February 2021).

Di Maria, A., Eyckmans, J., Van Acker, K., 2018. Downcycling versus recycling of construction and demolition waste: combining LCA and LCC to support sustainable policy making. Waste Manage. 75, 3-21. doi:10.1016/j.wasman.2018.01.028.

Ekvall, T., Assefa, G., Bjorklund, A., et al., 2007. What life-cycle assessment does and does not do in assessments of waste management. Waste Manage. 27, 989-996. doi:10.1016/j.wasman.2007.02.015.

EMVISESA, 2020. Empresa Municipal de la Vivienda de Sevilla. https://www.emvisesa. org/(accessed 17 February 2021; currently only in Spanish).

EN, 2011. EN 15978:2011 - Sustainability of construction works - Assessment of environmental performance of buildings - Calculation method. Int. Stand.

EPA, 2019. Environmental Protection Agency. Solid waste management and greenhouse gasses. documentation for greenhouse gas emission and energy factors used in the waste reduction model (WARM). https://www.epa.gov/warm/versions-wastereduction-model-warm\#15/ (accessed 17 February 2021).

EPD International, 2020. https://www.environdec.com/home (accessed 17 February 2021).

European Commission, 2014. Commission Decision 2014/955/EU. Commission Decision of 18 December 2014 amending Decision 2000/532/EC on the list of waste pursuant to Directive 2008/98/EC of the European Parliament and of the Council Text with EEA relevance. Official Journal of the European Union L370/ 0044-0086.

European Commission, 2018a. Directive (EU) 2018/851 of the European Parliament and of the Council of 30 May 2018 amending Directive 2008/98/EC on waste.

European Commission, 2018b. 2018/C 124/01. Commission notice on technical guidance on the classification of waste.

European Commission, 2019. The European Green Deal. https://eur-lex.europa.eu/legalcontent/EN/TXT/?uri = CELEX:52019DC0640 (accessed 17 February 2021)

European Commission, 2020a. Buildings and construction. https://ec.europa.eu/growth/ industry/sustainability/built-environment_en (accessed 17 February 2021).

European Commission, 2020b. A new Circular Economy Action Plan. For a cleaner and more competitive Europe. https://eur-lex.europa.eu/legal-content/EN/TXT/? uri $=$ COM: 2020:98: FIN (accessed 17 February 2021).

European Commission, 2021. Legislative train schedule. A European Green Deal. Strategy for a Sustainable Built Environment. https://www.europarl.europa.eu/legislativetrain/theme-a-european-green-deal/file-strategy-for-a-sustainable-built-environment/ 01-2021 (accessed 17 February 2021).

European Commission-JRC-IES, 2011a. Joint Research Centre-Institute for Environment and Sustainability. Supporting environmentally sound decisions for waste management-a technical guide to life cycle thinking (LCT) and life cycle assessment (LCA) for waste experts and LCA practitioners. https://eplca.jrc.ec.europa.eu/uploads/wasteGuide-to-LCTLCA-for-C-D-waste-management-Final-ONLINE.pdf. (accessed 17 February 2021).

European Commission-JRC-IES, 2011b. Joint Research Centre-Institute for Environment and Sustainability. ILCD handbook, International Reference Life Cycle Data System (ILCD) Handbook, Recommendations for life cycle impact assessment in the European context. https://doi.org/10.2788/33030.

European Commission-JRC, 2016. Joint Research Centre. Green Public Procurement Criteria for Office Building Design, Construction and Management. https://ec.europa.eu/ environment/gpp/pdf/report gpp office buildings.pdf (accessed 17 February 2021).

European Commission-JRC, 2018. Joint Research Centre. Best Environmental Management Practice for the Waste Management Sector. Learning from frontrunners. https:// dx.doi.org/10.2760/50247 (accessed 17 February 2021).

European Commission-JRC, 2021. Joint Research Centre. Level(s) common framework. https://susproc.jrc.ec.europa.eu/product-bureau/product groups/412/documents (accessed 17 February 2021).

European Environment Agency, 2020. Construction and demolition waste: challenges and opportunities in a circular economy. https://www.eea.europa.eu/themes/waste/ waste-management/construction-and-demolition-waste-challenges/ (accessed 17 February 2021).

Eurostat, 2018. Waste statistics. https://ec.europa.eu/eurostat/statistics-explained/index. php?title = Waste_statistics\#Total_waste_generation (accessed 17 February 2021).

Finnveden, G., Hauschild, M.Z., Ekvall, T., Guinée, J., Heijungs, R., Hellweg, S., Koehler, A., Pennington, D., Suh, S., 2009. Recent developments in life cycle assessment. J Environ Manag 91, 1-21. doi:10.1016/j.jenvman.2009.06.018.
Frischknecht, R., Jungbluth, N., Althaus, H.J., Doka, G., Dones, R., Heck, T., Hellweg, S., Hischier, R., Nemecek, T., Rebitzer, G., Spielmann, M., 2005. The ecoinven database: overview and methodological framework. Int. J. Life Cycle Assess. 10 (1), 3-9. doi:10.1065/lca2004.10.181.1.

Gheewala, S.H., 2009. Editorial: LCA of waste management systems research opportunities. Int. J. Life Cycle Assess. 14, 589-590. doi:10.1007/s11367-009-0128-y.

Grant, T., James, K.L., 2005. Life Cycle Impact Data for Resource Recovery from C\&I and C\&D Waste in Victoria Final Report. Centre for Design at RMIT University, Melbourne, Victoria.

Guinée, J.B., Gorrée, M., Heijungs, R., et al., 2001. Life cycle assessment-an operationa guide to the ISO standards-parts 1, 2 and 3. In: Hague Minist. housing, Spat. Plan. Environ. Cent. Environ. Sci. (CML).

ISO, 2006a. ISO 14040:2006 Environmental management - Life Cycle Assessment - Principles and Framework.

ISO, 2006b. ISO 14044:2006 Environmental management-Life Cycle Assessment-Requirements and Guidelines.

Jaillon, L., Poon, C.S., Chiang, Y.H., 2008. Quantifying the waste reduction potential of using prefabrication in building construction in Hong Kong. Waste Manage. 29, 309-320. doi:10.1016/j.wasman.2008.02.015.

Jambeck, J., Weitz, K., Solo-Gabriele, H., Townsend, T., Thorneloe, S., 2007. CCA-treated wood disposed in landfills and life-cycle trade-offs with waste-to-energy and MSW landfill disposal. Waste Manage. 27 (8), S21-S28. doi:10.1016/ j.wasman.2007.02.011.

John, V., 2012. Derivation of reliable simplifications strategies for the comparative LCA of individual and "Typical" Newly Built Swiss Apartment Buildings. ETH Zurich. doi:10.3929/ethz-a-007607252.

Kellenberger, D., Althaus, H. J., Jungbluth, N. and Künniger, T., Lehmann, M., Thalmann, P., 2007. Life Cycle Inventories of Building Products. Final report ecoinvent data v2.0 No. 7. Swiss Centre for Life Cycle Inventories, Dübendorf, $\mathrm{CH}$.

Kellenberger, D., Althaus, H.J., 2009. Relevance of simplifications in LCA of building components. Build. Environ. 44, 818-825. doi:10.1016/j.buildenv.2008.06.002.

Llatas, C., 2011. A model for quantifying construction waste in projects according to the European Waste List. Waste Manage. 31, 1261-1276. doi:10.1016/ j.wasman.2011.01.023

Llatas, C., Osmani, M., 2016. Development and validation of a building design waste reduction model. Waste Manage. 56, 318-336. doi:10.1016/j.wasman.2016.05.026.

Malmqvist, T., Glaumann, M., Scarpellini, S., Zabalza, I., Aranda, A., Llera, E., Díaz, S., 2011. Life cycle assessment in buildings: the ENSLIC simplified method and guidelines. Energy 36, 1900-1907. doi:10.1016/j.energy.2010.03.026.

Marinković, S., Radonjanin, V., Malešev, M., Ignjatović, I., 2010. Comparative environmental assessment of natural and recycled aggregate concrete. Waste Manage. 30 (11), 2255-2264. doi:10.1016/j.wasman.2010.04.012.

Martínez, E., Nuñez, Y., Sobaberas, E., 2013. End of life of buildings: three alternatives, two scenarios. A case study. Int. J. Life Cycle Assess. 18, 1082-1088. doi:10.1007/ s11367-013-0566-4.

Mercante, I.T., Bovea, M.D., Ibanez-Fores, V., Arena, A.P., 2012. Life cycle assessment of construction and demolition waste management systems: a Spanish case study. Int. J. Life Cycle Assess. 17, 232-241. doi:10.1007/s11367-011-0350-2.

Nessi, S., Rigamonti, L., Grosso, M., 2013. Discussion on methods to include prevention activities in waste management LCA. Int. J. Life Cycle Assess. 18, 1358-1373. doi:10.1007/s11367-013-0570-8.

Ortiz, O., Pasqualino, J.C., Castells, F., 2010. Environmental performance of construction waste: comparing three scenarios from a case study in Catalonia, Spain. Waste Manage. 30, 646-654. doi:10.1016/j.wasman.2009.11.013.

Osmani, M., Glass, J., Price, A., 2008. Architects' perspectives on construction waste reduction by design. Waste Manage. 28, 1147-1158. doi:10.1016/ j.wasman.2007.05.011.

Pantini, S., Borghi, G., Rigamonti, L., 2018. Towards resource-efficient management of asphalt waste in lombardy region (italy): identification of effective strategies based on the LCA methodology. Waste Manage. 80, 423-434. doi:10.1016/ j.wasman.2018.09.035

Pantini, S., Rigamonti, L., 2020. Is selective demolition always a sustainable choice? Waste Manage. 103, 169-176. doi:10.1016/j.wasman.2019.12.033.

Penteado, C.S.G., Rosado, L.P., 2016. Comparison of scenarios for the integrated management of construction and demolition waste by life cycle assessment: a case study in brazil. Waste Manage. Res. 34 (10), 1026-1035. doi:10.1177/ $0734242 \times 16657605$.

Poon, C.S., Jaillon, L., 2002. A Guide for Minimizing Construction and Demolition Waste at the Design Stage. The Hong Kong Polytechnic University, Hong Kong.

Rivela, B., Hospido, A., Moreira, T., Feijoo, G., 2006. Life cycle inventory of particleboard a case study in the wood sector. Int. J. Life Cycle Assess. 11 (2), 106-113. doi:10.1065/lca2005.05.206.

Sakai, S., Yano, J., Hirai, Y., Asari, M., et al., 2017. Waste prevention for sustainable resource and waste management. J. Mater. Cycles Waste Manage. 19 (4), 1295-1313. doi:10.1007/s10163-017-0586-4.

Soust-Verdaguer, B., Llatas, C., García-Martínez, A., 2016. Simplification in life cycle assessment of single-family houses: a review of recent developments. Build. Environ. 103, 215-227. doi:10.1016/j.buildenv.2016.04.014.

Spanish Government, 2008. Real Decreto 105/2008, de 1 de febrero, por el que se Regula la Producción y Gestión de los Residuos de Construcción y Demolición (National Decree 105/2008, February 1, which Regulates the Production and Management of Construction and Demolition Waste). Ministry of the Presidency, Madrid, Spain. BOE 038 of $13 / 2 / 2008$

Spanish Government, 2015. Plan Estatal Marco de Gestión de Residuos (PEMAR) 2016-2022. Ministry of Agriculture, Food and Environment, Madrid, Spain. https: //www. 
miteco.gob.es/es/calidad-y-evaluacion-ambiental/planes-y-estrategias/

pemaraprobado6noviembrecondae_tcm30-170428.pdf/ (accessed 17 February 2021; currently only in Spanish).

Spanish Government, 2018. Ministry of Economy. Call research projects I+D, 2017. Development of a unified tool for the quantification and reduction of environmental social and economic impacts of life cycle buildings in Building Information Modeling (BIM) platforms. Ref. BIA2017-84830-R. https://investigacion.us.es/sisius/sis proyecto.php?idproy $=28472$ / (accessed 17 February 2021; currently only in Spanish).

Spanish National Institute of Statistics, 2017. Cuentas medioambientales. Cuenta de los Residuos/Estadística sobre generación de residuos. Año 2017. https://www.ine.es/ prensa/cma_2017_res.pdf/ (accessed 17 February 2021; currently only in Spanish).

Tam, V.W.Y., Shen, L.Y., Tam, C.M., 2007a. Assessing the levels of material wastage affected by sub-contracting relationships and projects types with their correlations. Build. Environ. 42 (3), 1471-1477. doi:10.1016/j.buildenv.2005.12.023.

Tam, V.W.Y., Tam, C.M., Zeng, S.X., Ng, W.C.Y., 2007b. Towards adoption of prefabrication in construction. Build. Environ. 42 (10), 3642-3654. doi:10.1016/ j.buildenv.2006.10.003.

Vitale, P., Arena, N., Di Gregorio, F., Arena, U., 2017. Life cycle assessment of the end-of-life phase of a residential building. Waste Manage. 60, 311-321. doi:10.1016/ j.wasman.2016.10.002.

Won, J., Cheng, J.C., Lee, G., 2016. Quantification of construction waste prevented by BIM-based design validation: case studies in South Korea. Waste Manage. 49, 170-180. doi:10.1016/j.wasman.2015.12.026.

Xia, B., Ding, T., Xiao, J., 2020. Life cycle assessment of concrete structures with reuse and recycling strategies: a novel framework and case study. Waste Manage. 105, 268-278. doi:10.1016/j.wasman.2020.02.015.

Yazdanbakhsh, A., 2018. A bi-level environmental impact assessment framework for comparing construction and demolition waste management strategies. Waste Manage. 77, 401-412. doi:10.1016/j.wasman.2018.04.024.

Yuan, H., Shen, L., 2011. Trend of the research on construction and demolition waste management. Waste Manage. 31, 670-679. doi:10.1016/j.wasman.2010.10.030.

Zabalza Bribián, I., Aranda Usón, A., Scarpellini, S., 2009. Life cycle assessment in buildings: state-of-the-art and simplified LCA methodology as a complement for building certification. Build. Environ. 44, 2510-2520. doi:10.1016/ j.buildenv.2009.05.001. 